JPPMS, Vol. 3, No. 1, 2019

Jurnal Penelitian Pendidikan Matematika dan Sains

http://journal.unesa.ac.id/index.php/jppms/

\title{
KEMAMPUAN BERPIKIR KRITIS SISWA SMP DALAM MEMECAHKAN MASALAH MATEMATIKA DITINJAU DARI GAYA KOGNITIF
}

\author{
Oleh: \\ Wanda Ika Narianti ${ }^{1 *}$, Masriyah $^{l}$ \\ ${ }^{1}$ Jurusan Matematika FMIPA Universitas Negeri Surabaya \\ 1*wandanarianti16030174078@unesa.ac.id
}

\begin{abstract}
Abstrak - Kemampuan berpikir kritis adalah kecakapan memecahkan masalah yang dilakukan seseorang secara sistematis dan reflektif dalam mengolah informasi yang diperoleh ketika dihadapkan pada suatu masalah. Melalui berpikir kritis, siswa dapat mengambil keputusan secara tepat untuk memecahkan masalah tersebut. Akan tetapi dalam pembelajaran matematika, kemampuan berpikir kritis kurang mendapat perhatian karena seringkali siswa mendapatkan soal yang dalam proses mengerjakannya menggunakan prosedur rutin. Selain itu, juga perlu memperhatikan gaya kognitif siswa karena setiap siswa memiliki karateristik yang berbeda dalam waktu yang diperlukan untuk menjawab soal dan kesalahan jawaban yang dihasilkan. Penelitian ini merupakan penelitian deskriptif kualitatif, yang bertujuan untuk mendeskripsikan kemampuan berpikir kritis siswa SMP yang bergaya kognitif reflektif, impulsif, fast accurate, dan slow inaccurate dalam memecahkan masalah matematika. Subjek dalam penelitian ini adalah siswa SMP kelas VIII yang bergaya kognitif reflektif, impulsif, fast accurate, dan slow inaccurate masing-masing sebanyak 1 siswa. Teknik pengumpulan data dalam penelitian ini menggunakan tes gaya kognitif MFFT (matching familiar figure test), tes kemampuan matematika, tes pemecahan masalah matematika, dan wawancara. Teknik analisis data berdasarkan indikator kemampuan berpikir kritis yang meliputi klarifikasi, asesmen, inferensi, dan strategi pada setiap langkah pemecahan masalah. Hasil penelitian menunjukkan bahwa, siswa bergaya kognitif reflektif mampu melakukan klarifikasi, asesmen, dan inferensi. Siswa bergaya kognitif impulsif mampu melakukan strategi. Siswa bergaya kognitif fast accurate tidak mampu melakukan klarifikasi, asesmen, inferensi, dan strategi. Siswa bergaya kognitif slow inaccurate mampu melakukan asesmen.
\end{abstract}

Kata kunci: Kemampuan Berpikir Kritis, Memecahkan Masalah, Gaya Kognitif

\begin{abstract}
Critical thinking abilities is the ability to solve problems by someone systematically and reflectively in processing information obtained when faced with a problem. Through critical thinking, students can make appropriate decisions to solve these problems. However, in learning mathematics, critical thinking abilities receive less attention because students often get questions that in solved by using routine procedures. In addition to paying attention the critical thinking abilities, it is also necessary to pay attention to students' cognitive styles because each student has different characteristics in the time needed to answer questions and the resulting answer errors. This research is a qualitative descriptive study, which aims to describe the critical thinking abilities of junior high school students who have reflective, impulsive, fast accurate, and slow inaccurate cognitive styles in solving mathematical problems. The subjects in this study were eighth-grade junior high school students who had reflective, impulsive, fast accurate, and slow inaccurate cognitive styles of 1 student each. Data collection techniques in this study used the MFFT cognitive style test (matching familiar figure test), mathematics ability test, mathematical problems solving test and interviews. Data analysis techniques are based on indicators of critical thinking abilities that include clarification, assessment, inference, and strategy at each step of problems solving. The results showed that reflective cognitive style students were able to clarification, assessment, and inference. Impulsive cognitive style students can do the strategy. Fast accurate cognitive style students are not able to clarification, assessment, inference, and strategy. Slow inaccurate cognitive style students can do assessment.

Keywords: Critical Thinking Abilities, Problem Solving, Cognitive Style
\end{abstract}




\section{Pendahuluan}

Menurut Musfiqon (2015:2) pengembangan kurikulum dari KTSP (kurikulum tingkat satuan pendidikan) menjadi kurikulum 2013 berkonsekuensi terhadap perubahan kebijakan dalam standar pendidikan, terutama standar lulusan, standar isi, standar proses, dan standar evaluasi. Dengan demikian, pengembangan kurikulum selalu bersinggungan dengan strategi, metode, teknik, serta pendekatan pembelajaran. Pendekatan pembelajaran yang digunakan dalam kurikulum 2013 adalah pendekatan saintifik. Pendekatan saintifik menurut Musfiqon (2015:37) yaitu pendekatan yang menggunakan langkahlangkah serta kaidah ilmiah dalam proses pembelajaran. Langkah ilmiah yang diterapkan meliputi mengamati, menanya, mengumpulkan informasi, mengasosiasi atau menalar, dan mengkomunikasikan. Kegiatan mengasosiasi atau menalar terkait dengan kemampuan berpikir siswa, karena menurut Santrock (2009:7) tujuan dari berpikir adalah untuk membentuk konsep, mengasosiasi atau menalar, berpikir secara kritis, membuat keputusan, berpikir secara kreatif, dan memecahkan masalah. Sehingga dapat disimpulkan bahwa kemampuan berpikir menjadi aspek penting yang harus dikuasai oleh siswa.

Menurut Siswono (2008:12) berpikir merupakan suatu kegiatan mental yang dialami seseorang bila mereka dihadapkan pada suatu masalah atau situasi yang harus dipecahkan. Kegiatan mental yang dimaksud adalah pemrosesan informasi. Pernyataan tersebut sesuai dengan pendapat Santrock (2009:7) yang menyebutkan bahwa berpikir merupakan kegiatan yang melibatkan memanipulasi dan mentransformasi informasi dalam memori. Menurut Krulik \& Rudnick (dalam Siswono, 2008) tingkatan berpikir dibagi menjadi beberapa tingkatan yaitu mengingat, berpikir dasar, berpikir kritis, dan berpikir kreatif. Hal tersebut sesuai dengan karakteristik dari matematika, yaitu sebagai salah satu pelajaran yang diberikan di semua jenjang pendidikan dengan tujuan untuk membekali siswa kemampuan berpikir logis, analitis, sistematis, kritis, kreatif, serta kemampuan bekerja sama, Depdiknas (2007).

Pernyataan tersebut sejalan dengan pendapat Siswono (2008:3) yang mengatakan bahwa orientasi pembelajaran matematika saat ini diupayakan lebih menekankan pada pengajaran keterampilan berpikir tingkat tinggi, yaitu berpikir kritis dan berpikir kreatif. Berpikir kritis menurut Slavin (2011:37) dapat dipandang sebagai kemampuan mengambil keputusan rasional tentang apa yang harus dilakukan atau apa yang harus diyakini. Sementara itu, Siswono (2008:14) menyebutkan bahwa berpikir kritis adalah kemampuan berpikir siswa untuk membandingkan dua atau lebih informasi, misalkan informasi yang diterima dari luar dengan informasi yang dimiliki. Bila terdapat perbedaan atau persamaan, maka ia akan mengajukan pertanyan atau komentar dengan tujuan untuk mendapatkan penjelasan. Dengan demikian, berdasarkan uraian sebelumnya menunjukkan bahwa melalui matematika diharapkan siswa akan memiliki kemampuan berpikir kritis untuk menghadapi masalah-masalah yang mungkin timbul nantinya dalam kehidupan bermasyarakat yang selalu berkembang. Pernyataan tersebut didukung oleh pendapat Santrock (dalam Desmita, 2009) yang menegaskan bahwa "critical thinking can and should be used not just in the classroom, but outside is as well" yang artinya bahwa berpikir kritis dapat dan harus digunakan tidak hanya di dalam kelas melainkan juga di luar kelas.

Dalam usaha mendorong kemampuan berpikir kritis siswa pada matematika, digunakan konsep masalah dalam situasi tugas. Suatu tugas dikatakan masalah bagi siswa jika ia menyadari keberadaan situasi tersebut dan mengakui bahwa situasi tersebut memerlukan tindakan dan tidak dengan segera dapat menemukan pemecahannya. Untuk dapat memecahkan masalah tersebut, siswa harus melalui beberapa langkah pemecahan masalah. Menurut Siswono (2008:35) pemecahan masalah adalah suatu proses atau upaya individu untuk merespon atau mengatasi halangan atau kendala ketika suatu jawaban atau metode jawaban belum tampak jelas. Langkah pemecahan masalah menurut Polya (1973:5-19) terdiri dari empat langkah yaitu memahami masalah atau understanding the problem (mengidentifikasi datadata penting yang diketahui dan kondisi masalah yang dihadapi), membuat rencana penyelesaian atau devising a plan (merencanakan sejumlah langkah yang akan dilakukan untuk memecahkan masalah), melaksanakan rencana penyelesaian atau carrying out the plan (melaksanakan rencana yang telah disusun sebelumnya, namun jika diperlukan dapat dilakukan revisi dan modifikasi dari rencana yang sudah dibuat sebelumnya), dan memeriksa kembali atau looking back (mengecek kembali hasil pemecahan masalah yang sudah dilakukan, meliputi pengunaan seluruh informasi yang penting, memutuskan logis atau tidaknya jawaban atau solusi yang diperoleh, dan mengecek semua jawaban yang diperoleh apakah sesuai dengan kondisi dari masalah). Dengan demikian, pada setiap langkah pemecahan masalah memerlukan berpikir kritis.

Dalam memecahkan masalah, siswa akan menggunakan berbagai macam strategi. Menurut 
Susan \& Collinson (dalam Rofi'ah, 2018) bahwa "general problem solving strategies such as these are further influenced by cognitive style". Maksudnya adalah strategi pemecahan masalah ternyata banyak dipengaruhi oleh gaya kognitif siswa. Menurut Desmita (2009:146) di dalam gaya kognitif terdapat karakteristik individu yang berbeda dalam penggunaan fungsi kognitif (berpikir, mengingat, memecahkan masalah, membuat keputusan, mengorganisasi dan memproses informasi, dan seterusnya) yang bersifat konsisten dan berlangsung lama. Setiap individu akan memilih cara yang lebih disukai dalam memproses dan mengorganisir informasi sebagai respons terhadap stimuli lingkungannya. Kemungkinan ada individu yang memberikan respons lebih cepat, tetapi ada pula yang lebih lambat. Cara-cara memberi respon terhadap stimuli ini berkaitan erat dengan sikap dan kualitas personal. Hal tersebut menunjukkan bahwa siswa yang memiliki gaya kognitif yang berbeda, maka dalam memproses informasi atau menghadapi suatu tugas dan memecahkan masalah juga berbeda, sehingga perbedaan itu juga dimungkinkan akan mempengaruhi perbedaan berpikir kritis mereka. Selain itu, menurut Siswono (2008:35) ada beberapa faktor yang mempengaruhi kemampuan siswa dalam memecahkan masalah meliputi rasa takut (pobia) terhadap matematika, kemampuan matematika siswa yang berbeda-beda, keinginan dan motivasi siswa untuk memecahkan masalah matematika, serta struktur masalah matematika (format secara verbal atau gambar, kompleksitas, konteks, bahasa soal) yang diberikan. Sehingga, agar hasil penelitian ini nantinya hanya dipengaruhi oleh gaya kognitif siswa, maka peneliti akan memilih siswa yang memiliki kemampuan matematika setara, memiliki keinginan dan motivasi yang sama untuk memecahkan masalah matematika, menganggap bahwa semua siswa tidak memiliki rasa takut (pobia) terhadap matematika, dan memberikan struktur masalah matematika yang sama untuk setiap subjek penelitian nantinya.

Masalah matematika yang disajikan kepada siswa nantinya tidak harus dalam bentuk soal cerita, karena ada beberapa jenis masalah matematika yang bisa diberikan kepada siswa dengan tujuan untuk meminimalisir kebosanan dalam diri mereka. Dalam penelitian ini, peneliti menggunakan masalah menemukan untuk mengetahui kemampuan berpikir kritis siswa.

Berdasarkan laporan hasil ujian nasional tahun 2019 (Puspendik, Kemendikbud 2019) menyebutkan bahwa rata-rata nilai mata pelajaran matematika baik dalam jenjang SMP (rata-rata nilai Bahasa Indonesia 65,69; rata-rata nilai Bahasa
Inggris 50,23; rata-rata nilai matematika 46,56; dan rata-rata nilai IPA 48,79) maupun MTS (rata-rata nilai Bahasa Indonesia 61,06; rata-rata nilai Bahasa Inggris 45,94; rata-rata nilai matematika 42,24; dan rata-rata nilai IPA 44,61) menempati posisi terendah dari empat mata pelajaran yang diujikan dalam ujian nasional. Materi yang terdapat dalam ujian nasional mata pelajaran matematika meliputi bilangan, aljabar, geometri dan pengukuran, serta statistika dan peluang. Menurut Sumiati (2020:321) dalam penelitiannya menyebutkan bahwa letak kesulitan siswa dalam mengerjakan soal geometri dan pengukuran, khususnya materi segitiga dan segiempat meliputi kesulitan dalam memahami soal, kesulitan dalam menerjemahkan soal ke dalam model matematika, kesulitan untuk menentukan langkah awal untuk mengerjakan soal dengan tepat, siswa tidak bisa menerapkan soal yang diberikan ke dalam rumus yang berkaitan, dan siswa belum memahami konsep dari segitiga dan segiempat. Hal tersebut menunjukkan bahwa siswa belum menerapkan kemampuan berpikir kritis dalam memecahkan masalah matematika. Selain itu, beberapa peneliti juga telah melakukan penelitian tentang berpikir kritis siswa dalam memecahkan masalah matematika, di antaranya adalah (1) penelitian yang dilakukan oleh Nigsih (2012) yang berjudul "Profil Berpikir Kritis Siswa SMP dalam Menyelesaikan Masalah Matematika Berdasarkan Gaya Kognitif". Hasil penelitiannya menunjukkan bahwa, siswa bergaya kognitif reflektif memiliki ciri-ciri membutuhkan waktu yang lama dalam menyelesaikan masalah dan akurat sehingga jawaban cenderung benar. Siswa bergaya kognitif impulsif memiliki ciri-ciri membutuhkan waktu yang singkat dalam menyelesaikan masalah, tetapi tidak akurat sehingga jawaban cenderung salah. Siswa bergaya kognitif fast accurate memiliki ciri-ciri membutuhkan waktu yang singkat dalam menyelesaikan masalah dan akurat sehingga jawaban cenderung benar. Siswa yang bergaya kognitif slow inaccurate memiliki ciri-ciri membutuhkan waktu yang lama dalam menyelesaikan masalah, tetapi tidak akurat sehingga jawaban cenderung salah. Penelitian yang akan peneliti lakukan memiliki persamaan dengan penelitian Ningsih yaitu membahas berpikir kritis siswa dalam menyelesaikan masalah matematika berdasarkan gaya kognitif (reflektif, impulsif, fast accurate, dan slow inaccurate). Sementara itu perbedaannya terletak pada subjek penelitian, materi, dan karakteristik soal pemecahan masalah yang digunakan adalah tidak dalam bentuk soal cerita. (2) penelitian yang dilakukan oleh Nisa' (2015) yang berjudul "Profil Berpikir Kritis Siswa SMP dalam Menyelesaikan Soal Cerita Ditinjau 
dari Gaya Kognitif dan Kemampuan Matematika”. Hasil penelitiannya menunjukkan bahwa profil berpikir kritis siswa dengan kemampuan matematika berbeda dan gaya kognitif reflektif, dalam menyelesaikan soal cerita cenderung sama. Hal tersebut ditunjukkan, bahwa siswa dengan kemampuan matematika tinggi yang bergaya kognitif reflektif memenuhi semua kriteria IDEALS (identify, define, enumerate, analyze, list, self-correct), sementara itu siswa dengan kemampuan matematika rendah yang bergaya kognitif reflektif juga memenuhi semua kriteria IDEALS (identify, define, enumerate, analyze, list, self-correct), namun hasil akhir yang diperoleh belum benar karena ada langkah yang salah pada metode yang digunakan. Begitu pula dengan profil berpikir kritis siswa dengan kemampuan matematika berbeda dan gaya kognitif impulsif, dalam menyelesaikan soal cerita juga cenderung sama. Hal tersebut ditunjukkan, bahwa siswa dengan kemampuan matematika tinggi yang bergaya kognitif impulsif memenuhi kriteria identify, define, enumerate, analyze, list, namun dalam self-correct siswa hanya mengecek hasil akhirnya saja. Siswa dengan kemampuan matematika rendah yang bergaya kognitif impulsif memenuhi kriteria yang hampir sama dengan siswa kemampuan matematika tinggi yang bergaya kognitif impulsif, namun dalam setiap langkah, siswa cenderung melakukan semua hal dengan cepat sehingga tidak semua informasi yang ada terungkap dan menyebabkan hasil akhirnya belum benar. Kesamaan dengan penelitian ini terletak pada berpikir kritis siswa berdasarkan gaya kognitif (reflektif dan impulsif). Sementara itu perbedaannya terletak pada subjek penelitian, materi, karakteristik soal pemecahan masalahnya tidak dalam bentuk soal cerita, indikator kemampuan berpikir kritis yang digunakan adalah kriteria klarifikasi, asesmen, inferensi, dan strategi, bukan kriteria IDEALS (identify, define, enumerate, analyze, list, self-correct) dan penelitian ini tidak hanya ditinjau berdasarkan gaya kognitif tetapi juga berdasarkan kemampuan matematika siswa yang setara. (3) penelitian yang dilakukan oleh Mbagho (2015) yang berjudul "Profil Berpikir Kritis Siswa SMP dalam Memecahkan Masalah Geometri Kontekstual Ditinjau dari Perbedaan Kemampuan Matematika". Hasil penelitian menunjukkan bahwa, subjek berkemampuan matematika tinggi, dalam memecahkan masalah melakukan keempat langkah pemecahan masalah Polya yaitu memahami masalah, membuat rencana penyelesaian, melaksankan rencana penyelesaian, dan memeriksa kembali. Subjek berkemampuan matematika sedang, dalam memecahkan masalah hanya melakukan tiga langkah pemecahan masalah Polya yaitu memahami masalah, membuat rencana penyelesaian, melaksankan rencana penyelesaian, namun tidak memeriksa kembali. Subjek berkemampuan matematika rendah, dalam memecahkan masalah melakukan keempat langkah pemecahan masalah Polya yaitu memahami masalah, membuat rencana penyelesaian, melaksankan rencana penyelesaian, dan memeriksa kembali (namun hanya hasil akhirnya saja yang diperiksa). Sehingga penelitian tersebut dikatakan relevan dengan penelitian yang akan peneliti lakukan, karena memiliki persamaan dalam hal berpikir kritis siswa dalam menyelesaikan masalah matematika. Sementara itu perbedaannya terletak pada subjek penelitian, karakteristik soal pemecahan masalah yang digunakan adalah tidak dalam bentuk soal cerita, dan penelitian tersebut hanya ditinjau dari kemampuan matematika siswa saja.

Berdasarkan uraian tersebut, peneliti tertarik untuk melakukan penelitian yang berjudul "Kemampuan Berpikir Kritis Siswa SMP dalam Memecahkan Masalah Matematika Ditinjau dari Gaya Kognitif”.

\section{Metode}

Penelitian ini menggunakan pendekatan kualitatif dan prosedur penelitian deskriptif, yang bertujuan untuk mendeskripsikan kemampuan berpikir kritis siswa SMP yang bergaya kognitif reflektif (RE), impulsif (IM), fast accurate (FA), dan slow inaccurate (SI) dalam memecahkan masalah matematika.

Pengambilan data dilaksanakan di SMP Negeri 1 Mojosari kelas VIII E. Subjek dalam penelitian ini adalah siswa bergaya kognitif RE, IM, FA, dan SI masing-masing sebanyak 1 siswa yang telah menerima materi bangun datar.

Dalam penelitian ini terdapat 3 tes yaitu tes gaya kognitif MFFT (matching familiar figure test) untuk memperoleh data tentang gaya kognitif siswa, tes kemampuan matematika (TKM) untuk mengetahui siswa yang memiliki kemampuan matematika setara, tes pemecahan masalah matematika (TPMM) untuk mengetahui kemampuan berpikir kritis siswa dalam memecahkan masalah matematika, serta wawancara yang digunakan untuk mengeksplorasi dan melengkapi informasi mengenai bagaimana kemampuan berpikir kritis siswa dalam memecahkan masalah matematika sekaligus juga untuk memvalidasi jawaban siswa yang sudah tertulis dalam TPMM.

Data hasil tes gaya kognitif MFFT (matching familiar figure test) dianalisis berdasarkan dua aspek penting yaitu waktu yang 
dipergunakan siswa untuk menjawab semua soal yang diberikan $(t)$ dan banyaknya jawaban salah siswa $(f)$. Selanjutnya data hasil TKM akan dianalisis dengan menggunakan pedoman penskoran yang telah dibuat oleh peneliti dan dikatakan setara jika selisih skor TKM kurang dari atau sama dengan 5 dalam skala 100. Sementara itu hasil TPMM dan wawancara akan dianalisis menggunakan alternatif kemampuan siswa dalam memecahkan masalah matematika yang telah dibuat oleh peneliti berdasarkan indikator kemampuan berpikir kritis sebagai berikut.

Tabel 1. Indikator Kemampuan Berpikir Kritis Siswa pada Setiap Langkah Pemecahan Masalah

\begin{tabular}{|c|c|c|}
\hline $\begin{array}{c}\text { Kemampuan } \\
\text { Berpikir Kritis }\end{array}$ & Indikator & Kode \\
\hline \multirow{4}{*}{$\begin{array}{l}\text { Klarifikasi (pada } \\
\text { langkah memahami } \\
\text { masalah) }\end{array}$} & $\begin{array}{l}\text { Mampu menyebutkan informasi-informasi yang terdapat } \\
\text { pada soal }\end{array}$ & MK1 \\
\hline & Mampu menentukan pokok permasalahan secara tepat & MK2 \\
\hline & $\begin{array}{l}\text { Mampu mengaitkan informasi-informasi yang saling } \\
\text { berhubungan dan mengaitkan permasalahan dengan materi } \\
\text { lain yang akan digunakan dalam penyelesaian }\end{array}$ & MK3 \\
\hline & $\begin{array}{l}\text { Mampu mendefinisikan istilah-istilah yang relevan dari } \\
\text { permasalahan yang diberikan }\end{array}$ & MK4 \\
\hline \multirow{3}{*}{$\begin{array}{l}\text { Asesmen (pada } \\
\text { langkah memahami } \\
\text { masalah) }\end{array}$} & $\begin{array}{l}\text { Mampu menyebutkan informasi-informasi relevan yang } \\
\text { terdapat pada soal }\end{array}$ & MA1 \\
\hline & $\begin{array}{l}\text { Mampu mendeskripsikan alasan terhadap informasi- } \\
\text { informasi relevan yang telah ditemukan }\end{array}$ & MA2 \\
\hline & $\begin{array}{l}\text { Mampu menentukan informasi relevan yang tepat yang } \\
\text { akan digunakan untuk mendapatkan solusi penyelesaian }\end{array}$ & MA3 \\
\hline \multirow{2}{*}{$\begin{array}{l}\text { Strategi (pada } \\
\text { langkah membuat } \\
\text { rencana } \\
\text { penyelesaian) }\end{array}$} & $\begin{array}{l}\text { Mampu menentukan langkah-langkah yang akan digunakan } \\
\text { untuk mendapatkan solusi penyelesaian }\end{array}$ & MS1 \\
\hline & $\begin{array}{l}\text { Mampu memprediksi hasil dari langkah-langkah yang telah } \\
\text { ditentukan sebelumnya dengan tepat beserta alasan yang } \\
\text { masuk akal }\end{array}$ & MS2 \\
\hline \multirow{3}{*}{$\begin{array}{l}\text { Inferensi (pada } \\
\text { langkah } \\
\text { melaksanakan } \\
\text { rencana } \\
\text { penyelesaian) }\end{array}$} & $\begin{array}{l}\text { Mampu melaksanakan pemecahan masalah menggunakan } \\
\text { langkah-langkah yang telah direncanakan sebelumnya }\end{array}$ & MI1 \\
\hline & $\begin{array}{l}\text { Mampu menyimpulkan secara tepat sesuai dengan solusi } \\
\text { yang didapatkan dari langkah-langkah pemecahan masalah } \\
\text { yang telah dilakukan }\end{array}$ & MI2 \\
\hline & $\begin{array}{l}\text { Mampu mendeskripsikan alasan yang tepat mengenai } \\
\text { kesimpulan yang didapatkan }\end{array}$ & MI3 \\
\hline \multirow{2}{*}{$\begin{array}{l}\text { Strategi (pada } \\
\text { langkah memeriksa } \\
\text { kembali) }\end{array}$} & $\begin{array}{l}\text { Mampu memeriksa kembali langkah-langkah yang telah } \\
\text { dilakukan }\end{array}$ & MS3 \\
\hline & $\begin{array}{l}\text { Mampu menentukan langkah lain yang sesuai sehingga } \\
\text { dapat digunakan untuk mendapatkan solusi penyelesaian }\end{array}$ & MS4 \\
\hline $\begin{array}{l}\text { Inferensi (pada } \\
\text { langkah memeriksa } \\
\text { kembali) }\end{array}$ & $\begin{array}{l}\text { Mampu membuat generalisasi, sesuai dengan hasil yang } \\
\text { diperoleh dengan tepat }\end{array}$ & MI4 \\
\hline
\end{tabular}

\section{Hasil dan Pembahasan}

Langkah pertama penelitian ini adalah dengan memberikan tes gaya kognitif MFFT (matching familiar figure test) kepada seluruh siswa kelas VIII E, dengan alokasi waktu mengerjakan adalah 40 menit. Kemudian dilanjutkan dengan memberikan TKM dengan alokasi waktu mengerjakan sebanyak 60 menit, sehingga didapatkan data sebagai berikut.

Tabel 2. Hasil Tes Gaya Kognitif MFFT dan TKM

\begin{tabular}{l|l|c|c|c|c}
\hline \multicolumn{1}{c|}{ No. } & \multicolumn{1}{|c|}{ Nama } & $\boldsymbol{f}$ & $\boldsymbol{t}$ & $\begin{array}{c}\text { Gaya } \\
\text { Kognitf }\end{array}$ & $\begin{array}{c}\text { Nilai } \\
\text { TKM }\end{array}$ \\
\hline 1. & APW & 8 & 12,58 & IM & 46 \\
2. & ANP & 9 & 12,58 & IM & 47 \\
3. & AAC & 3 & 16,46 & RE & 74 \\
4. & APA & 6 & 14,01 & FA & 79 \\
5. & ASHSP & 5 & 13,34 & FA & 51 \\
6. & BA & 6 & 14,06 & FA & 80 \\
7. & DJP & 5 & 16,57 & RE & 71 \\
8. & DHBW & 5 & 12,32 & FA & 43 \\
\hline
\end{tabular}




\begin{tabular}{l|l|c|c|c|c}
\hline No. & \multicolumn{1}{|c|}{ Nama } & $\boldsymbol{f}$ & $\boldsymbol{t}$ & $\begin{array}{c}\text { Gaya } \\
\text { Kognitf }\end{array}$ & $\begin{array}{c}\text { Nilai } \\
\text { TKM }\end{array}$ \\
\hline 9. & DFA & 7 & 18,28 & SI & 61 \\
10. & EDP & 5 & 13,51 & FA & 49 \\
11. & FT & 4 & 19,30 & RE & 34 \\
12. & FARP & 4 & 17,18 & RE & 66 \\
13. & FA & 5 & 15,06 & FA & 47 \\
14. & GIR & 6 & 12,59 & FA & 77 \\
15. & HD & 12 & 15,14 & IM & 36 \\
16. & H & 4 & 18,49 & RE & 47 \\
17. & JCZ & 6 & 12,32 & FA & 53 \\
18. & LFN & 4 & 19,17 & RE & 54 \\
19. & MRA & 3 & 17,59 & RE & 67 \\
20. & MAHA & 7 & 17,41 & SI & 80 \\
21. & MSH & 9 & 13,45 & IM & 62 \\
22. & MIZ & 5 & 20,29 & RE & 32 \\
23. & MRAP & 9 & 12,59 & IM & 60 \\
24. & MYDF & 5 & 17,40 & RE & 36 \\
25. & NEME & 5 & 18,54 & RE & 71 \\
26. & NRDS & 4 & 18,28 & RE & 81 \\
27. & NANA & 3 & 17,50 & RE & 74 \\
28. & NBN & 7 & 13,45 & IM & 42 \\
29. & SDA & 7 & 14,40 & IM & 80 \\
30. & SKN & 4 & 19,03 & RE & 66 \\
31. & WST & 10 & 12,33 & IM & 78 \\
32. & ZSA & 2 & 17,57 & RE & 60 \\
\hline & & & & & \\
\hline
\end{tabular}

Berdasarkan analisis hasil tes gaya kognitif dan TKM tersebut, akan dipilih siswa yang memiliki kemampuan matematika setara dengan jenis gaya kognitif yang berbeda, selain itu juga didasarkan pada pertimbangan dari guru mata pelajaran matematika (guru mitra) tentang siswa yang memiliki kemampuan komunikasi yang baik. Dengan demikian, siswa yang terpilih menjadi subjek penelitian yaitu sebagai berikut.

Tabel 3. Subjek Penelitian

\begin{tabular}{l|l|c|c|c|c}
\hline No. & \multicolumn{1}{|c|}{ Nama } & $\boldsymbol{f}$ & $\boldsymbol{t}$ & $\begin{array}{c}\text { Gaya } \\
\text { Kognitf }\end{array}$ & $\begin{array}{c}\text { Nilai } \\
\text { TKM }\end{array}$ \\
\hline 1. & GIR & 6 & 12,59 & FA & 77 \\
2. & MAHA & 7 & 17,41 & SI & 80 \\
3. & NRDS & 4 & 18,28 & RE & 81 \\
4. & WST & 10 & 12,33 & IM & 78 \\
\hline
\end{tabular}

Selanjutnya, subjek penelitian tersebut diberikan TPMM. TPMM yang digunakan dalam penelitian ini terdiri dari satu butir soal uraian materi bangun datar, dengan alokasi waktu mengerjakan selama 60 menit. Kemudian dilanjutkan dengan wawancara terhadap subjek penelitian terkait dengan TPMM yang sudah dikerjakan.

Untuk mempermudah penyajian data, maka dibuat kode penyajian data hasil wawancara sebagai berikut.

Tabel 4. Kode Transkrip Wawancara

\begin{tabular}{|c|c|c|}
\hline No. & $\begin{array}{c}\text { Kode } \\
\text { Wawancara }\end{array}$ & Keterangan \\
\hline 1. & $\mathrm{QRE}_{\mathrm{y}}$ & $\begin{array}{l}\text { Pertanyaan peneliti ke-y untuk subjek penelitian bergaya kognitif } \\
\text { reflektif }\end{array}$ \\
\hline 2. & $\mathrm{ARE}_{\mathrm{y}}$ & Jawaban ke-y dari subjek penelitian bergaya kognitif reflektif \\
\hline 3. & $\mathrm{QIM}_{\mathrm{y}}$ & $\begin{array}{l}\text { Pertanyaan peneliti ke-y untuk subjek penelitian bergaya kognitif } \\
\text { impulsif }\end{array}$ \\
\hline 4. & $\mathrm{AIM}_{\mathrm{y}}$ & Jawaban ke-y dari subjek penelitian bergaya kognitif impulsif \\
\hline 5. & $\mathrm{QFA}_{\mathrm{y}}$ & $\begin{array}{l}\text { Pertanyaan peneliti ke-y untuk subjek penelitian bergaya kognitif fast } \\
\text { accurate }\end{array}$ \\
\hline 6. & $\mathrm{AFA}_{\mathrm{y}}$ & Jawaban ke-y dari subjek penelitian bergaya kognitif fast accurate \\
\hline
\end{tabular}


Wanda Ika Narianti, JPPMS, 2019, Vol. 3, No. 1, halaman 27

\begin{tabular}{l|l|l}
\hline No. & \multicolumn{1}{|c|}{$\begin{array}{c}\text { Kode } \\
\text { Wawancara }\end{array}$} & \multicolumn{1}{c}{ Keterangan } \\
\hline 7. & $\mathrm{QSI}_{\mathrm{y}}$ & $\begin{array}{l}\text { Pertanyaan peneliti ke-y untuk subjek penelitian bergaya kognitif } \text { slow } \\
\text { inaccurate } \\
\text { Jawaban ke-y dari subjek penelitian bergaya kognitif slow inaccurate }\end{array}$ \\
\hline
\end{tabular}

\section{Kemampuan Berpikir Kritis Siswa SMP yang Bergaya Kognitif Reflektif dalam Memecahkan Masalah Matematika}

Berikut ini akan disajikan transkrip wawancara terhadap subjek RE mengenai kemampuan berpikir kritis pada langkah memahami masalah.

Tabel 5. Transkrip Wawancara Subjek RE pada Langkah Memahami Masalah

\begin{tabular}{|c|c|}
\hline $\begin{array}{c}\text { Kode } \\
\text { Wawancara }\end{array}$ & Transkrip Wawancara \\
\hline $\mathrm{QRE}_{1}$ & Berapa kali kamu membaca soal yang terdapat pada tes pemecahan masalah itu? \\
\hline $\mathrm{ARE}_{1}$ & Tiga \\
\hline $\mathrm{QRE}_{2}$ & Coba kamu sebutkan apa saja yang diketahui dari soal? \\
\hline $\mathrm{ARE}_{2}$ & Diketahui panjang sisi persegi kecil dan jumlahnya persegi kecil ada 4 .......MK1 \\
\hline $\mathrm{QRE}_{3}$ & Berhubungan dengan materi apakah soal tersebut? \\
\hline $\mathrm{ARE}_{3}$ & Lingkaran \\
\hline $\mathrm{QRE}_{4}$ & $\begin{array}{l}\text { Coba kamu jelaskan kembali soal yang ada pada tes pemecahan masalah } \\
\text { matematika tersebut dengan menggunakan bahasamu sendiri! Intinya soal tersebut } \\
\text { tentang apa? }\end{array}$ \\
\hline $\mathrm{ARE}_{4}$ & Mencari luas daerah yang diarsir \\
\hline $\mathrm{QRE}_{5}$ & Apa yang ditanyakan dari soal? \\
\hline $\mathrm{ARE}_{5}$ & Menentukan luas daerah yang diarsir .......MK2 \\
\hline $\mathrm{QRE}_{6}$ & $\begin{array}{l}\text { Apakah terdapat hubungan antara yang diketahui dengan yang ditanyakan? Jika } \\
\text { iya hubungannya itu apa? }\end{array}$ \\
\hline $\mathrm{ARE}_{6}$ & $\begin{array}{l}\text { Hubungannya kalau yang diketahui sama yang ditanyakan adalah dikurangi. } \\
\text { Misalnya panjang sisi persegi kecil } 10 \mathrm{~cm} \text {, kemudian bisa dicari luas persegi } \\
\text { kecilnya. Selain itu juga bisa dicari luas seperempat lingkaran. Kemudian luas } \\
\text { persegi kecil dikurangi dengan luas seperempat lingkaran diperoleh luas daerah } \\
\text { yang diarsir.......MK3 }\end{array}$ \\
\hline $\mathrm{QRE}_{7}$ & $\begin{array}{l}\text { Menurut pendapat kamu apakah soal ini berhubungan dengan materi lain pada } \\
\text { matematika? }\end{array}$ \\
\hline $\mathrm{ARE}_{7}$ & Segitiga ........MK3 \\
\hline $\mathrm{QRE}_{8}$ & Apa saja kata kunci yang terdapat dalam soal tersebut? \\
\hline $\mathrm{ARE}_{8}$ & Empat persegi sama ukuran dengan panjang sisinya $10 \mathrm{~cm}$.......MK4 \\
\hline $\mathrm{QRE}_{9}$ & Coba kamu sebutkan informasi-informasi yang saling berhubungan pada soal! \\
\hline $\mathrm{ARE}_{9}$ & $\begin{array}{l}\text { Masing-masing persegi kecil memiliki panjang sisi } 10 \mathrm{~cm} \text { dan memiliki hubungan } \\
\text { dengan seperempat lingkaran dan segitiga .......MA1 } \\
\text { Mengapa informasi-informasi yang kamu sebutkan tadi saling berhubungan? }\end{array}$ \\
\hline $\mathrm{QRE}_{10}$ & Alasannya kenapa bisa saling berhubungan? \\
\hline $\mathrm{ARE}_{10}$ & Karena bisa digunakan untuk mencari jawabannya .......MA2 \\
\hline $\mathrm{QRE}_{11}$ & $\begin{array}{l}\text { Dari informasi-informasi yang telah kamu sebutkan tadi, manakah informasi yang } \\
\text { akan kamu gunakan untuk mendapatkan solusi penyelesaian? } \\
\text { Ini tadi, sama empat persegi sama ukuran } 10 \mathrm{~cm} \text { dan daerah yang diarsir (semua } \\
\text { informasi yang telah saya sebutkan) .......MA3 }\end{array}$ \\
\hline
\end{tabular}

Berdasarkan informasi pada Tabel 5, subjek RE membaca soal sebanyak 3 kali (ditunjukkan oleh $\mathrm{ARE}_{1}$ ). Dia mampu menyebutkan informasi yang diketahui (ditunjukkan oleh MK1) dan informasi yang ditanyakan (ditunjukkan oleh MK2). Hal tersebut sejalan dengan Ardani (2017) yang menyebutkan bahwa subjek mampu mengidentifikasi asumsi pokok dari permasalahan dengan mengumpulkan informasi-informasi yang diketahui dan ditanyakan. Dia juga mampu mendeskripsikan hubungan antara informasi yang diketahui dan ditanyakan (ditunjukkan oleh MK3), materi matematika yang terkait (ditunjukkan oleh MK3), dan kata kunci yang terdapat pada soal (ditunjukkan oleh MK4). Hal itu sesuai dengan Ardani (2017) yang menyebutkan bahwa subjek mampu mengidentifikasi hubungan bagian permasalahan dengan mengaitkan informasiinformasi yang saling berhubungan, mengaitkan permasalahan dengan materi yang 
akan digunakan dalam penyelesaian serta mendefinisikan istilah-istilah yang relevan dengan mendefinisikan kata-kata kunci yang terkait dengan permasalahan. Dengan demikian, dapat dikatakan bahwa dia mampu melakukan klarifikasi pada langkah memahami masalah. Selain itu dia juga mampu menyebutkan informasi-informasi yang saling berhubungan pada soal (ditunjukkan oleh MA1) disertai dengan alasan yang mendukung (ditunjukkan oleh MA2) sehingga mampu memutuskan informasi mana yang akan digunakan untuk mendapatkan solusi penyelesaian (ditunjukkan oleh MA3). Hal tersebut sejalan dengan Ardani (2017) yang menyebutkan bahwa subjek mampu mengumpulkan informasi yang relevan dengan mengidentifikasi informasi-informasi yang saling berhubungan disertai dengan alasannya. Hal tersebut juga sesuai dengan Dyah (2019) yang menyatakan bahwa by associating those stated and unstated information, the subject identified the relationships among them and took certain approach/strategy followed by the reason/claim behind the action dan juga sesuai dengan Fajriyah (2019) yang menyatakan bahwa students with reflective cognitive style were able to master reasoning and argumentation, sehingga dapat dikatakan bahwa dia mampu melakukan asesmen pada langkah memahami masalah.

Berikutnya akan disajikan kutipan tes tertulis dan transkrip wawancara subjek RE mengenai kemampuan berpikir kritis pada langkah membuat rencana penyelesaian.

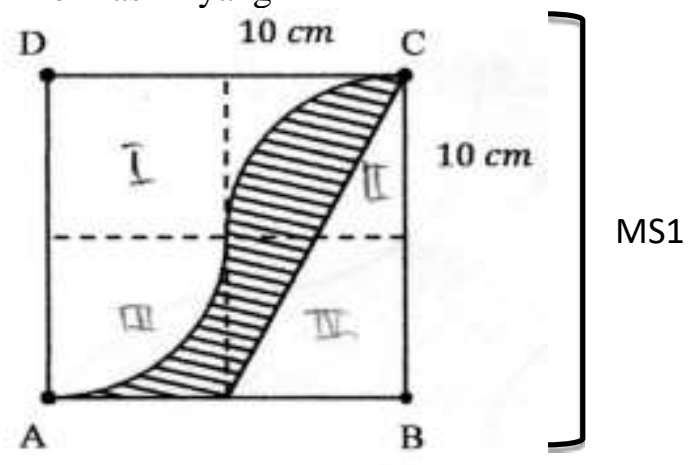

Gambar 1. Kutipan Jawaban Subjek RE pada Langkah Membuat Rencana Penyelesaian

Tabel 6. Transkrip Wawancara Subjek RE pada Langkah Membuat Rencana Penyelesaian

\begin{tabular}{|c|c|}
\hline $\begin{array}{c}\text { Kode } \\
\text { Wawancara }\end{array}$ & Transkrip Wawancara \\
\hline $\mathrm{QRE}_{12}$ & $\begin{array}{l}\text { Kamu kan habis membaca soal, pasti memikirkan menggunakan cara apa ya ini? } \\
\text { Terus kamu kan pasti memikirkan langkah-langkahnya. Langkah-langkah apa } \\
\text { yang kamu lakukan untuk mendapatkan solusi penyelesaian dari soal tersebut? }\end{array}$ \\
\hline $\mathrm{ARE}_{12}$ & $\begin{array}{l}\text { Mencari luas persegi yang kecil terus mencari luas seperempat lingkaran terus } \\
\text { mencari luas segitiga. Kemudian luas persegi kecil dikurangi dengan luas } \\
\text { seperempat lingkaran maka akan didapatkan luas daerah yang diarsir (bagian III). } \\
\text { Selanjutnya menjumlahkan luas seperempat lingkaran dan luas persegi kecil, lalu } \\
\text { hasilnya dikurangi dengan luas segitiga maka akan didapatkan luas daerah diarsir } \\
\text { yang lain (bagian IV) ........MS1 }\end{array}$ \\
\hline $\mathrm{QRE}_{13}$ & $\begin{array}{l}\text { Berdasarkan langkah-langkah yang telah kamu susun, bisakah kamu } \\
\text { memperkirakan bagiamana hasil akhir yang kamu dapatkan? Misalnya hasilnya } \\
\text { nanti bilangan bulat, desimalkah? }\end{array}$ \\
\hline $\mathrm{ARE}_{13}$ & $\begin{array}{l}\text { Enggak, karena nanti kalau luas daerah yang diarsir ini dijadikan satu, maka akan } \\
\text { terbentuk persegi kecil. Berarti luasnya sama dengan } 100 \mathrm{~cm}^{2} \text {. Sehingga saya } \\
\text { gak berpikiran kalau hasilnya bentuk desimal .......MS2 }\end{array}$ \\
\hline
\end{tabular}

Berdasarkan informasi pada Gambar 1 dan Tabel 6, subjek RE mampu menentukan langkah-langkah yang akan digunakan untuk mendapatkan solusi penyelesaian, yaitu dengan membagi gambar menjadi beberapa bagian dan mencari luas daerah yang diarsir secara satu persatu (ditunjukkan dengan MS1). Hal itu sesuai dengan Ardani (2017) yang menyatakan bahwa subjek mampu mengusulkan langkah spesifik mengarah pada solusi dengan menentukan langkah-langkah yang akan digunakan dalam menyelesaiakan permasalahan dan sesuai dengan pendapat Fajriyah (2019) yang menyebutkan bahwa students with reflective cognitive style were able to devising strategies for solving problems very well, serta juga sesuai dengan pendapat Dyah (2019) yang menyatakan bahwa subject 
chose certain strategies and took some steps to solve problem. Setelah itu, dia juga mampu menganalisis bahwa hasil akhir dari luas daerah yang diarsir nanti adalah berupa luas dari persegi kecil (ditunjukkan dengan MS2). Hal tersebut sejalan dengan Ardani (2017) yang menyebutkan bahwa subjek mampu memprediksi hasil dari langkah yang dibuat dengan membuat beberapa dugaan sementara terkait dengan hasil penyelesaian. Dengan demikian, dapat dikatakan bahwa dia mampu melakukan strategi pada langkah membuat rencana penyelesaian.

Selanjutnya akan disajikan kutipan tes tertulis dan transkrip wawancara subjek RE mengenai kemampuan berpikir kritis pada langkah melaksanakan rencana penyelesaian.

MI2

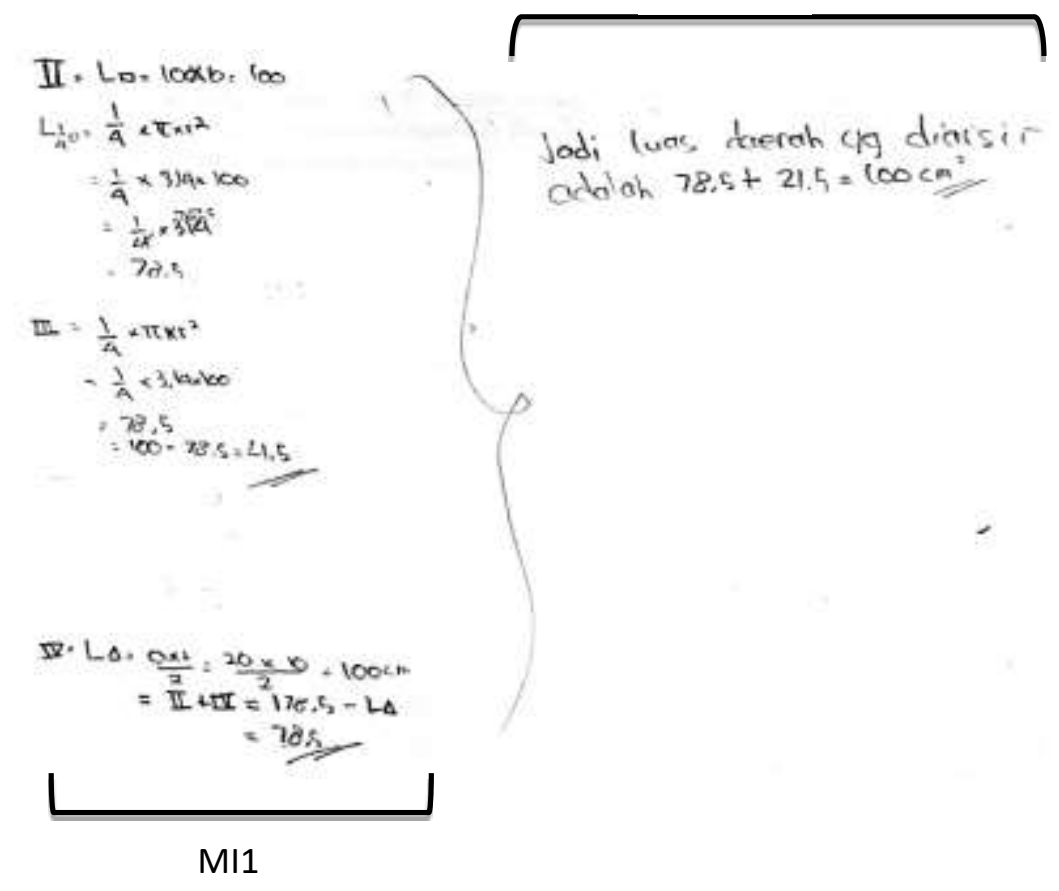

Gambar 2. Kutipan Jawaban Subjek RE pada Langkah Melaksanakan Rencana Penyelesaian

Tabel 7. Transkrip Wawancara Subjek RE pada Langkah Melaksanakan Rencana Penyelesaian

\begin{tabular}{|c|c|}
\hline $\begin{array}{c}\text { Kode } \\
\text { Wawancara }\end{array}$ & Transkrip Wawancara \\
\hline $\mathrm{QRE}_{14}$ & $\begin{array}{l}\text { Kan habis memikirkan langkah-langkahnya kan kamu melakukan perhitungan. } \\
\text { Nah, pas kamu melakukan perhitungan apakah tetap menggunakan langkah- } \\
\text { langkah awal mu tadi atau langkah-langkahnya ada yang kamu tambahi atau } \\
\text { kurangi? }\end{array}$ \\
\hline $\mathrm{ARE}_{14}$ & Langkah-langkahnya sama seperti yang saya pikirkan .......MI1 \\
\hline $\mathrm{QRE}_{15}$ & Setelah perhitunganmu selesai, kesimpulan apa yang kamu dapatkan? \\
\hline $\mathrm{ARE}_{15}$ & Luas daerah yang diarsir adalah $100 \mathrm{~cm}^{2} \ldots \ldots$....MI2 \\
\hline $\mathrm{QRE}_{16}$ & $\begin{array}{l}\text { Apakah kamu yakin bahwa kesimpulanmu yang tadi (luas daerah yang diarsir } \\
100 \mathrm{~cm}^{2} \text { ) sudah sesuai dengan yang ditanyakan pada soal? }\end{array}$ \\
\hline $\mathrm{ARE}_{16}$ & $\begin{array}{l}\text { Sesuai, karena nanti kalau luas daerah yang diarsir ini dijadikan satu, maka akan } \\
\text { terbentuk persegi kecil .......MI3 }\end{array}$ \\
\hline
\end{tabular}

Berdasarkan informasi pada Gambar 2 dan Tabel 7, subjek RE mampu melaksanakan semua langkah-langkah yang telah direncanakan sebelumnya (ditunjukkan oleh MI1), sehingga dapat menarik kesimpulan yang tepat (ditunjukkan oleh MI2) berdasarkan alasan yang masuk akal (ditunjukkan oleh MI3). Hal tersebut sejalan dengan Ardani (2017) yang menyatakan bahwa subjek mampu membuat kesimpulan dengan benar disertai dengan alasan yang tepat, selain itu juga sesuai dengan Ningsih (2012) yang menyebutkan bahwa siswa reflektif mampu menarik kesimpulan dengan tepat. Dengan demikian, dapat dikatakan bahwa dia mampu melakukan inferensi pada langkah melaksanakan rencana penyelesaian. 
Kemudian, berikut ini juga akan disajikan transkrip wawancara terhadap subjek RE mengenai mengenai kemampuan berpikir kritis pada langkah memeriksa kembali.

Tabel 8. Transkrip Wawancara Subjek RE pada Langkah Memeriksa Kembali

\begin{tabular}{|c|c|}
\hline $\begin{array}{c}\text { Kode } \\
\text { Wawancara }\end{array}$ & Transkrip Wawancara \\
\hline $\mathrm{QRE}_{17}$ & $\begin{array}{l}\text { Apakah kamu memeriksa kembali langkah-langkah mu dari awal sampai akhir } \\
\text { sampai didapatkan solusi penyelesaian. }\end{array}$ \\
\hline $\mathrm{ARE}_{17}$ & Iya ........MS3 \\
\hline $\mathrm{QRE}_{18}$ & $\begin{array}{l}\text { Setelah kamu periksa, apakah kamu memikirkan cara lain yang dapat kamu } \\
\text { gunakan selain langkah-langkah yang telah kamu tulis ini untuk mendapatkan } \\
\text { luas daerah yang diarsir ini? }\end{array}$ \\
\hline $\mathrm{ARE}_{18}$ & Tidak \\
\hline $\mathrm{QRE}_{19}$ & $\begin{array}{l}\text { Kesimpulan apakah yang kamu peroleh setelah melakukan serangkaian proses } \\
\text { untuk mendapatkan solusi penyelesaian dari soal tersebut? }\end{array}$ \\
\hline $\mathrm{ARE}_{19}$ & $\begin{array}{l}\text { Persegi, lingkaran, dan segitiga memiliki hubungan dalam soal ini dan luas daerah } \\
\text { yang diarsir adalah } 100 \mathrm{~cm}^{2} \ldots . . . \mathrm{MI} 4\end{array}$ \\
\hline
\end{tabular}

Berdasarkan informasi pada Tabel 8, subjek RE mampu memeriksa kembali semua langkah yang telah dilakukan dari awal sampai akhir (ditunjukkan oleh MS3). Hal tersebut sesuai dengan Ardani (2017) yang menyatakan bahwa subjek mampu mengevaluasi langkah penyelesaian yang telah dilakukan, dan sejalan dengan Ningsih (2012) yang menyebutkan bahwa siswa reflektif melakukan overview setelah selesai mengerjakan, serta sesuai dengan Dyah (2019) yang menyebutkan bahwa subject considered her judgment carefully, so that she could find some mistake if any tried to revise the answer and change the conclusion. Namun, dia tidak mampu menemukan cara lain yang dapat digunakan untuk mendapatkan solusi penyelesaian tersebut (ditunjukkan oleh $\mathrm{ARE}_{18}$ ). Hal tersebut berbeda dengan Ardani (2017) yang menyebutkan bahwa subjek mendiskusikan langkah yang mungkin dengan menyebutkan langkah lain selain yang dipilihnya. Perbedaan tersebut dapat terjadi dikarenakan waktu mengerjakan yang diberikan hampir habis. Dengan demikian, dapat dikatakan bahwa dia tidak mampu melakukan strategi pada langkah memeriksa kembali. Selain itu, dia juga mampu membuat generalisasi (ditunjukkan oleh MI4), sehingga dapat dikatakan bahwa dia mampu melakukan inferensi pada langkah memeriksa kembali.

2. Kemampuan Berpikir Kritis Siswa SMP yang Bergaya Kognitif Impulsif dalam Memecahkan Masalah Matematika

Berikut ini akan disajikan transkrip wawancara terhadap subjek IM mengenai kemampuan berpikir kritis pada langkah memahami masalah.

Tabel 9. Transkrip Wawancara Subjek IM pada Langkah Memahami Masalah

\begin{tabular}{c|l}
$\begin{array}{c}\text { Kode } \\
\text { Wawancara }\end{array}$ & \multicolumn{1}{c}{ Transkrip Wawancara } \\
\hline QIM $_{1}$ & $\begin{array}{l}\text { Berapa kali kamu membaca soal yang terdapat pada tes pemecahan masalah } \\
\text { matematika? }\end{array}$ \\
AIM $_{1}$ & $\begin{array}{l}\text { Cuma satu kali waktu itu } \\
\text { Coba kamu sebutkan apa saja yang diketahui dari soal? }\end{array}$ \\
IIM $_{2}$ & $\begin{array}{l}\text { Ukuran sisi persegi kecil 10 cm dan jumlah persegi kecilnya ada 4 .......MK1 } \\
\text { AIM }\end{array}$ \\
QIM $_{3}$ & $\begin{array}{l}\text { Berhubungan dengan materi apakah soal tersebut? } \\
\text { Berhubungan dengan materi lingkaran, mencari luas }\end{array}$ \\
QIM $_{3}$ & $\begin{array}{l}\text { Coba kamu jelaskan kembali soal yang ada pada tes pemecahan masalah dengan } \\
\text { menggunakan bahasamu sendiri! }\end{array}$ \\
AIM $_{4}$ & $\begin{array}{l}\text { Di sini kan diketahui persegi ABCD tersusun dari 4 persegi kecil, dimana persegi } \\
\text { kecil ini memiliki panjang sisi 10 } \mathrm{cm} . \text { Kemudian disuruh mencari luas daerah } \\
\text { yang diarsir. }\end{array}$ \\
QIM & $\begin{array}{l}\text { Coba kamu jelaskan apa yang ditanyakan pada soal? } \\
\text { Yang ditanyakan adalah luas daerah yang diarsir seperti pada gambar .......MK2 } \\
\text { AIM }\end{array}$ \\
QIM $_{6}$ & $\begin{array}{l}\text { Apakah terdapat hubungan antara yang diketahui dengan yang ditanyakan? Jika } \\
\text { iya hubungannya itu apa? } \\
\text { Ada hubungannya. Disini kan ada persegi kecil, dimana di persegi kecil itu ada } \\
\text { daerah yang diarsir, sehingga tinggal dikurangi aja luas perseginya dan luas } \\
\text { daerah yang diarsir. } \\
\text { Menurut pendapat kamu apakah soal ini berhubungan dengan materi lain dalam } \\
\text { matematika? }\end{array}$ \\
\hline
\end{tabular}




\begin{tabular}{|c|c|}
\hline $\begin{array}{c}\text { Kode } \\
\text { Wawancara }\end{array}$ & Transkrip Wawancara \\
\hline $\begin{array}{l}\mathrm{AIM}_{7} \\
\mathrm{QIM}_{8}\end{array}$ & $\begin{array}{l}\text { Tentang luas bangun datar .......MK3 } \\
\text { Apa saja kata kunci yang terdapat dalam soal tersebut? }\end{array}$ \\
\hline $\begin{array}{l}\text { AIM }_{8} \\
\text { QIM }_{9} \\
\text { AIM }_{9}\end{array}$ & $\begin{array}{l}\text { Kata kuncinya cuma panjang sisi persegi kecil } 10 \mathrm{~cm} \text {.......MK4 } \\
\text { Coba kamu sebutkan informasi-informasi yang saling berhubungan pada soal! } \\
\text { Masing-masing persegi kecil memiliki panjang sisi } 10 \mathrm{~cm} \text {, kemudian disuruh } \\
\text { mencari luas persegi kecil itu sendiri kan } 100 \mathrm{~cm}^{2} \text {, kalau luas persegi besarnya } \\
\text { itu adalah } 400 \mathrm{~cm}^{2} \text {. Hubungan yang lain adalah kalau daerah yang diarsir ini } \\
\text { digabung maka akan membentuk persegi kecil, sedangkan luas dari persegi kecil } \\
\text { itu sendiri adalah } 100 \mathrm{~cm}^{2} \text {. }\end{array}$ \\
\hline $\mathrm{QIM}_{10}$ & $\begin{array}{l}\text { Mengapa informasi-informasi yang kamu sebutkan saling berhubungan? } \\
\text { Alasannya kenapa bisa saling berhubungan? }\end{array}$ \\
\hline $\mathrm{AIM}_{10}$ & Karena soal itu sendiri memiliki informasi yang sangat jelas \\
\hline $\mathrm{QIM}_{11}$ & $\begin{array}{l}\text { Dari informasi-informasi yang telah kamu sebutkan, informasi manakah yang } \\
\text { akan kamu gunakan untuk mendapatkan solusi penyelesaian? }\end{array}$ \\
\hline $\mathrm{AIM}_{11}$ & Informasi tentang panjang sisi persegi kecil .......MA3 \\
\hline
\end{tabular}

Berdasarkan pada Tabel 9, subjek IM hanya perlu membaca soal sebanyak 1 kali (ditunjukkan oleh $\mathrm{AIM}_{1}$ ). Dia mampu menyebutkan informasi yang diketahui (ditunjukkan oleh MK1) dan informasi yang ditanyakan (ditunjukkan oleh MK2). Hal tersebut sesuai dengan Ardani (2017) yang menyatakan bahwa subjek mampu mengidentifikasi asumsi pokok dari permasalahan dengan mengumpulkan informasi-informasi yang diketahui dan ditanyakan. Namun dia tidak mampu menyebutkan hubungan antara keduanya (ditunjukkan oleh AIM $_{6 .}$ ) Hal tersebut sejalan dengan Dyah (2019) yang menyatakan bahwa she was not able to identify the relationship among informations completely, namun berbeda dengan Ardani (2017) yang menyatakan bahwa subjek mampu mengidentifikasi hubungan bagian permasalahan dengan mengaitkan informasiinformasi yang saling berhubungan. Perbedaan tersebut dapat terjadi disebabkan oleh subjek yang terburu-buru dalam menjawab pertanyaan yang diajukan sehingga jawaban yang diberikan tidak tepat. Tetapi dia mampu mengaitkan dengan materi matematika yang akan digunakan dalam penyelesaian (ditunjukkan oleh MK3) dan mampu mendefinisikan istilahistilah yang relevan dengan menyebutkan katakata kunci yang terkait dengan permasalahan (ditunjukkan oleh MK4). Hal tersebut sejalan dengan Ardani (2017) yang menyebutkan bahwa subjek mampu mengaitkan permasalahan dengan materi yang akan digunakan dalam penyelesaian serta mampu mendefiniskan istilah-istilah yang relevan dengan mendefinisikan kata-kata kunci yang terkait dengan permasalahan. Dengan demikian, dapat dikatakan bahwa dia tidak mampu melakukan klarifikasi pada langkah memahami masalah. Selain itu dia juga tidak mampu menyebutkan informasi-informasi yang saling berhubungan pada soal dan juga alasannya (ditunjukkan oleh $\mathrm{AIM}_{9}$ dan $\mathrm{AIM}_{10}$ ), namun mampu memutuskan informasi mana yang akan digunakan untuk mendapatkan solusi penyelesaian (ditunjukkan oleh MA3). Hal tersebut sesuai dengan Dyah (2019) yang menyebutkan bahwa the impulsive subject often held her believe eventhough she did not know the reason of it dan juga sesuai dengan Ardani (2017) yang menyatatakan bahwa subjek mampu membuat keputusan pada argumen dengan memilih informasi-informasi relevan yang tepat digunakan dalam penyelesaian masalah, sehingga dapat dikatakan bahwa dia tidak mampu melakukan asesmen pada langkah memahami masalah.

Berikutnya akan disajikan kutipan tes tertulis dan transkrip wawancara subjek IM mengenai kemampuan berpikir kritis pada langkah membuat rencana penyelesaian.

Berdasarkan informasi pada Gambar 3 dan Tabel 10, subjek IM mampu menentukan langkah-langkah yang akan digunakan untuk mendapatkan solusi penyelesaian yaitu dengan mengamati gambar pada soal secara saksama, kemudian membaginya menjadi 4 bagian, dan menganalisisnya sehingga diperoleh hasil analisis bahwa luas daerah yang diarsir tersebut jika dijadikan satu maka akan membentuk satu persegi kecil (ditunjukkan oleh MS1). Hal tersebut sesuai dengan Ardani (2017) yang menyebutkan bahwa subjek mampu mengusulkan langkah spesifik mengarah pada solusi dengan menentukan langkah-langkah yang akan digunakan dalam penyelesaian masalah. 


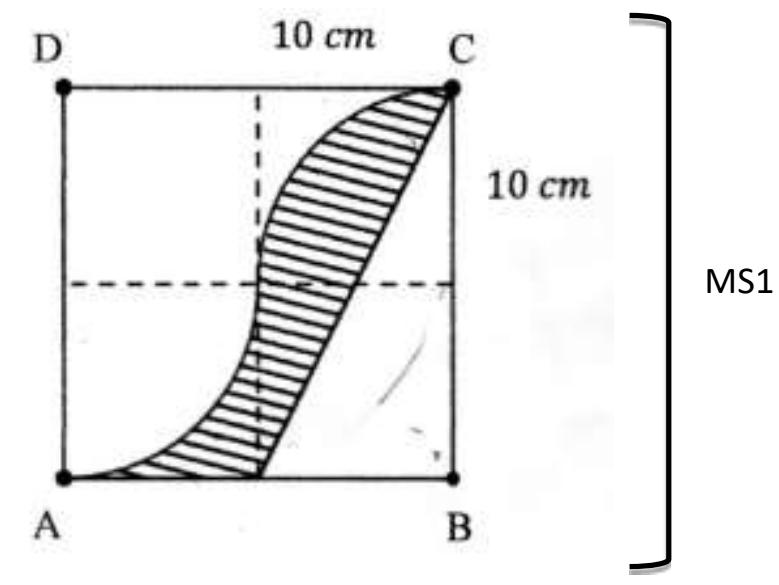

Gambar 3. Kutipan Jawaban Subjek IM pada Langkah Membuat Rencana Penyelesaian

Tabel 10. Transkrip Wawancara Subjek IM pada Langkah Membuat Rencana Penyelesaian

\begin{tabular}{|l|l|}
\hline $\begin{array}{c}\text { Kawan- } \\
\text { cara }\end{array}$ & \multicolumn{1}{c|}{ Transkrip Wawancara } \\
\hline QIM $_{12}$ & $\begin{array}{l}\text { Langkah-langkah apa yang kamu lakukan untuk mendapatkan solusi penyelesaian } \\
\text { dari soal tersebut? }\end{array}$ \\
\hline AIM $_{12}$ & $\begin{array}{l}\text { Pertama mengamati gambar, lalu dilihat kalau daerah yang diarsir ini bisa } \\
\text { dihubungkan dan bisa membentuk persegi kecil. Luas persegi kecil dikurangi } \\
\text { dengan luas seperempat lingkaran akan didapatkan luas daerah yang diarsir. Luas } \\
\text { daerah diarsir tersebut kan sama dengan luas daerah kecil yang tidak diarsir, } \\
\text { sehingga daerah yang diarsir tersebut bisa dipindahkan ke daerah yang tidak } \\
\text { diarsir tersebut. Segitiga kecil yang diarsir kan sama dengan segitiga kecil yang } \\
\text { tidak diarsir, karena ukurannya sama ........MS1 }\end{array}$ \\
\hline QIM $_{13}$ & $\begin{array}{l}\text { Berdasarkan langkah-langkah yang telah kamu susun, bisakah kamu } \\
\text { memperkirakan bagiamana hasil akhir yang kamu dapatkan? }\end{array}$ \\
\hline AIM $_{13}$ & $\begin{array}{l}\text { Bisa, hasil akhirnya nanti kan setelah digabungkan itu membentuk persegi kecil. } \\
\text { Sedangkan di soal yang ditanyakan adalah luas daerah yang diarsir, ternyata } \\
\text { bentuk dari luas daerah yang diarsir sama dengan persegi kecil. Jadinya kalau } \\
\text { ditanya luas, kita mencari luas persegi kecil saja ........MS2 }\end{array}$ \\
\hline
\end{tabular}

Selain itu, dia juga mampu memprediksi hasil dari langkah-langkah yang telah ditentukan sebelumnya dengan tepat beserta alasan yang masuk akal (ditunjukkan oleh MS2). Dengan demikian, dapat dikatakan bahwa dia mampu melakukan strategi pada langkah membuat rencana penyelesaian.

Selanjutnya akan disajikan kutipan tes tertulis dan transkrip wawancara subjek IM mengenai kemampuan berpikir kritis pada langkah melaksanakan rencana penyelesaian.

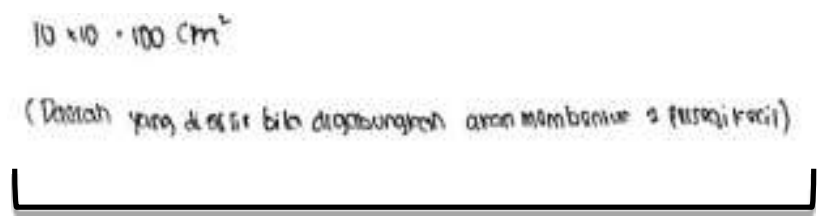

MI1

Gambar 4. Kutipan Jawaban Subjek IM pada Langkah Melaksanakan Rencana Penyelesaian

Tabel 11. Transkrip Wawancara Subjek IM pada Langkah Melaksanakan Rencana Penyelesaian

\begin{tabular}{c|l}
\hline $\begin{array}{c}\text { Kode } \\
\text { Wawancara }\end{array}$ & \multicolumn{1}{c}{ Transkrip Wawancara } \\
\hline QIM $_{14}$ & $\begin{array}{l}\text { Kan habis memikirkan langkah-langkahnya kan kamu melakukan perhitungan. } \\
\text { Nah, pas kamu melakukan perhitungan apakah tetap menggunakan langkah- } \\
\text { langkah awal mu tadi atau langkah-langkahnya ada yang kamu tambahi atau } \\
\text { kurangi? } \\
\text { Tetap memakai langkah-langkah itu .......MI1 }\end{array}$ \\
\hline
\end{tabular}




\begin{tabular}{c|l}
\hline $\begin{array}{c}\text { Kode } \\
\text { Wawancara }\end{array}$ & \multicolumn{1}{c}{ Transkrip Wawancara } \\
\hline QIM $_{15}$ & Setelah perhitunganmu selesai, kesimpulan apa yang kamu dapatkan? \\
AIM $_{15}$ & Luas daerah yang diarsir sama dengan luas persegi kecil yaitu $100 \mathrm{~cm}^{2} \ldots . . . . \mathrm{MI} 2$ \\
QIM $_{16}$ & $\begin{array}{l}\text { Apakah kamu yakin bahwa kesimpulanmu yang tadi sudah sesuai dengan yang } \\
\text { ditanyakan pada soal? }\end{array}$ \\
AIM $_{16}$ & Yakin, karena saya kan sudah menemukan luas daerah yang diarsir. \\
\hline
\end{tabular}

Berdasarkan informasi pada Gambar 4 dan Tabel 11, subjek IM mampu melaksanakan semua langkah-langkah yang telah direncanakan sebelumnya (ditunjukkan oleh MI1), sehingga dapat menarik kesimpulan yang tepat (ditunjukkan oleh MI2), namun tidak mampu memberikan alasan yang masuk akal (ditunjukkan oleh $\mathrm{AIM}_{16}$ ). Hal itu sejalan dengan Ardani (2017) yang menyebutkan bahwa subjek mampu membuat kesimpulan dari langkah-langkah yang telah dilakukan. Dengan demikian, dapat dikatakan bahwa dia tidak mampu melakukan inferensi pada langkah melaksanakan rencana penyelesaian.

Kemudian, berikut ini akan disajikan transkrip wawancara terhadap subjek IM mengenai kemampuan berpikir kritis pada langkah memeriksa kembali.

Tabel 12. Transkrip Wawancara Subjek IM pada Langkah Memeriksa Kembali

\begin{tabular}{c|l}
$\begin{array}{c}\text { Kode } \\
\text { Wawancara }\end{array}$ & \multicolumn{1}{c}{ Transkrip Wawancara } \\
\hline QIM $_{17}$ & $\begin{array}{l}\text { Apakah kamu memeriksa kembali langkah-langkah mu dari awal sampai ahkir } \\
\text { sampai didapatkan solusi penyelesaian? } \\
\text { Memeriksa kembali dari awal sampai akhir, supaya jawabannya semakin yakin } \\
\text {......MS3 } \\
\text { Apakah ada cara lain yang dapat kamu gunakan selain langkah-langkah yang } \\
\text { telah kamu tulis ini untuk mendapatkan luas daerah yang diarsir ini? } \\
\text { Ada, yaitu dengan menghitung luas daerah yang diarsir satu persatu .......MS4 }\end{array}$ \\
QIM $_{18}$ & $\begin{array}{l}\text { Kesimpulan apakah yang kamu peroleh setelah melakukan serangkaian proses } \\
\text { untuk mendapatkan solusi penyelesaian dari soal tersebut? } \\
\text { Kalau luas daerah yang diarsir dipindahkan maka akan membentuk persegi kecil } \\
\text { yaitu 100 } \mathrm{cm}^{2} \text {........MI4 }\end{array}$ \\
QIM $_{19}$ &
\end{tabular}

Berdasarkan informasi pada Tabel 12, subjek IM mampu memeriksa kembali semua langkah yang telah dilakukan dari awal sampai akhir (ditunjukkan oleh MS3). Hal tersebut berbeda dengan Ardani (2017) yang menyebutkan bahwa subjek tidak mampu mengevaluasi langkah penyelesaian yang telah dilakukan, selain itu juga berbeda dengan Ningsih (2012) yang menyatakan bahwa siswa impulsif tidak melakukan overview. Dia juga mampu menemukan cara lain yang dapat digunakan untuk mendapatkan solusi penyelesaian tersebut (ditunjukkan oleh MS4). Hal tersebut juga berbeda dengan Ardani (2017) yang menyebutkan bahwa subjek tidak mampu mendiskusikan langkah lain selain langkah yang disebutkan untuk memecahkan masalah dan juga berbeda dengan Appulembang (2017) yang menyatakan bahwa subjek tidak dapat menemukan cara baru dalam menyelesaikan masalah. Beberapa perbedaan tersebut dapat terjadi dikarenakan subjek bergaya kognitif impulsif tidak membutuhkan waktu lama dalam memecahkan soal tersebut, sehingga sisa waktu mengerjakan digunakan untuk mengecek ulang jawaban yang telah mereka dapatkan dan memikirkan cara lain yang dapat digunakan untuk mendapatkan solusi penyelesaian dari permasalahan tersebut. Dengan demikian, dapat dikatakan bahwa dia mampu melakukan strategi pada langkah memeriksa kembali. Selain itu, dia juga mampu membuat generalisasi (ditunjukkan oleh MI4), sehingga dapat dikatakan bahwa dia mampu melakukan inferensi pada langkah memeriksa kembali.

3. Kemampuan Berpikir Kritis Siswa SMP yang Bergaya Kognitif Fast Accurate dalam Memecahkan Masalah Matematika

Berikut ini akan disajikan kutipan tes tertulis dan transkrip wawancara subjek FA mengenai kemampuan berpikir kritis pada langkah memahami masalah. 


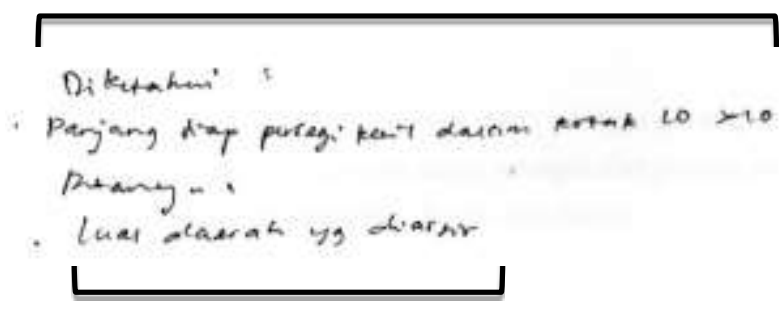

MK2

Gambar 5. Kutipan Jawaban Subjek FA pada Langkah Memahami Masalah

Tabel 13. Transkrip Wawancara Subjek FA pada Langkah Memahami Masalah

\begin{tabular}{|c|c|}
\hline $\begin{array}{c}\text { Kode } \\
\text { Wawancara }\end{array}$ & Transkrip Wawancara \\
\hline $\mathrm{QFA}_{1}$ & $\begin{array}{l}\text { Berapa kali kamu membaca soal yang terdapat pada tes pemecahan masalah } \\
\text { matematika? }\end{array}$ \\
\hline $\mathrm{AFA}_{1}$ & Dua kali, terus pas mengerjakan saat saya enggak bisa saya baca lagi. \\
\hline $\mathrm{QFA}_{2}$ & Coba kamu sebutkan apa saja yang diketahui dari soal? \\
\hline $\mathrm{AFA}_{2}$ & $\begin{array}{l}\text { Dari soal yang diketahui terdapat satu persegi utuh, kemudian di dalamnya } \\
\text { terdapat empat persegi kecil dan terdapat sebuah arsiran ........MK1 }\end{array}$ \\
\hline $\mathrm{QFA}_{3}$ & Berhubungan dengan materi apakah soal tersebut? \\
\hline $\mathrm{AFA}_{3}$ & Berhubungan dengan materi luas persegi dan luas lingkaran \\
\hline $\mathrm{QFA}_{4}$ & $\begin{array}{l}\text { Coba kamu jelaskan kembali soal yang ada pada tes pemecahan masalah ini } \\
\text { dengan menggunakan bahasamu sendiri! Jelaskan intinya soal menggunakan } \\
\text { bahasamu sendiri? }\end{array}$ \\
\hline $\mathrm{AFA}_{4}$ & Terdapat satu persegi, kemudian terdapat arsiran \\
\hline $\mathrm{QFA}_{5}$ & Coba kamu jelaskan apa yang ditanyakan dari soal? \\
\hline $\mathrm{AFA}_{5}$ & $\begin{array}{l}\text { Yang ditanyakan adalah menentukan luas daerah arsiran yang terdapat pada } \\
\text { gambar .......MK2 }\end{array}$ \\
\hline $\mathrm{QFA}_{6}$ & $\begin{array}{l}\text { Apakah terdapat hubungan antara yang diketahui dengan yang ditanyakan? Jika } \\
\text { iya hubungannya itu apa? }\end{array}$ \\
\hline $\mathrm{AFA}_{6}$ & $\begin{array}{l}\text { Iya jelas, soalnya enggak mungkin ditanyakan kalau tidak ada yang diketahui } \\
\text { (sehingga pasti ada hubungannya). }\end{array}$ \\
\hline $\mathrm{QFA}_{7}$ & $\begin{array}{l}\text { Menurut pendapat kamu apakah soal ini berhubungan dengan materi lain pada } \\
\text { matematika? }\end{array}$ \\
\hline $\mathrm{AFA}_{7}$ & Iya, lingkaran, persegi, dan segitiga siku-siku (bangun datar) .......MK3 \\
\hline $\mathrm{QFA}_{8}$ & Apa saja kata kunci yang terdapat dalam soal tersebut? \\
\hline $\mathrm{AFA}_{8}$ & $\begin{array}{l}\text { Tersusun dari empat persegi sama ukuran dengan panjang sisinya adalah } 10 \mathrm{~cm} \\
\text { dan melihat gambar yang diarsir .......MK4 }\end{array}$ \\
\hline $\mathrm{QFA}_{9}$ & Coba kamu sebutkan informasi-informasi yang saling berhubungan pada soal! \\
\hline $\mathrm{AFA}_{9}$ & $\begin{array}{l}\text { Yang berhubungan tersusun dari empat persegi kecil sama ukuran dengan panjang } \\
\text { sisi } 10 \mathrm{~cm} \text {, yang mana empat persegi kecil itu akan menyusun persegi ABCD. }\end{array}$ \\
\hline $\mathrm{QFA}_{10}$ & $\begin{array}{l}\text { Mengapa informasi-informasi yang kamu sebutkan tadi saling berhubungan? } \\
\text { Alasannya kenapa bisa saling berhubungan? }\end{array}$ \\
\hline $\mathrm{AFA}_{10}$ & $\begin{array}{l}\text { Karena itu yang menyusun satu persegi utuh, kan yang ditanyakan arsiran terus } \\
\text { itu disusun menjadi persegi ABCD. }\end{array}$ \\
\hline $\mathrm{QFA}_{11}$ & $\begin{array}{l}\text { Dari informasi-informasi yang telah kamu sebutkan tadi, informasi manakah yang } \\
\text { akan kamu gunakan untuk mendapatkan solusi penyelesaian? }\end{array}$ \\
\hline $\mathrm{AFA}_{11}$ & Arsiran, panjang sisi $10 \mathrm{~cm}$ (semua yang sudah saya sebutkan tadi) .......MA3 \\
\hline
\end{tabular}

Berdasarkan informasi pada Gambar 5 dan Tabel 13, subjek FA membaca soal sebanyak 2 kali, namun jika pada saat mengerjakan nanti mengalami kesulitan maka akan dibaca lagi (ditunjukkan oleh $\mathrm{AFA}_{1}$ ). Dia mampu menyebutkan informasi yang diketahui (ditunjukkan oleh MK1), informasi yang ditanyakan (ditunjukkan oleh MK2), namun tidak mampu mendeskripsikan hubungan antara keduanya (ditunjukkan oleh $\mathrm{AFA}_{6}$ ), tetapi mampu menyebutkan materi matematika yang terkait (ditunjukkan oleh MK3), dan kata kunci yang terdapat pada soal (ditunjukkan oleh MK4). Dengan demikian, dapat dikatakan bahwa dia tidak mampu melakukan klarifikasi pada langkah memahami masalah. Selain itu dia juga tidak mampu menyebutkan informasiinformasi yang saling berhubungan pada soal 
(ditunjukkan oleh $\mathrm{AFA}_{9}$ ) dan juga alasannya (ditunjukkan oleh $\mathrm{AFA}_{10}$ ), namun mampu memutuskan informasi mana yang akan digunakan untuk mendapatkan solusi penyelesaian (ditunjukkan oleh MA3), sehingga dapat dikatakan bahwa dia tidak mampu melakukan asesmen pada langkah memahami masalah.

Berikutnya akan disajikan kutipan tes tertulis dan transkrip wawancara subjek FA mengenai kemampuan berpikir kritis pada langkah membuat rencana penyelesaian.

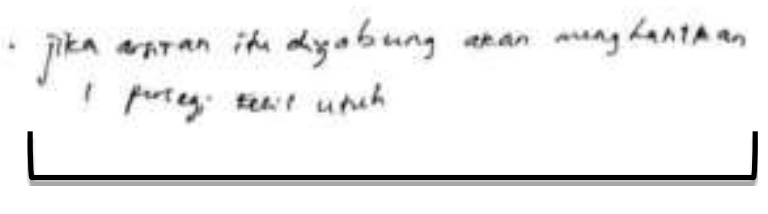

MS1

Gambar 6. Kutipan Jawaban Subjek FA pada Langkah Membuat Rencana Penyelesaian

Tabel 14. Transkrip Wawancara Subjek FA pada Langkah Membuat Rencana Penyelesaian

\begin{tabular}{c|l}
$\begin{array}{c}\text { Kode } \\
\text { Wawancara }\end{array}$ & \multicolumn{1}{c}{ Transkrip Wawancara } \\
\hline $\mathrm{QFA}_{12}$ & $\begin{array}{l}\text { Setelah kamu membaca soal, pasti kan kamu memikirkan langkah-langkah apa } \\
\text { yang harus kamu lakukan? Nah, angkah-langkah apa yang kamu lakukan untuk } \\
\text { mendapatkan solusi penyelesaian dari soal tersebut? }\end{array}$ \\
$\mathrm{AFA}_{12}$ & $\begin{array}{l}\text { Yang diketahui kan panjang sisi persegi kecil } 10 \mathrm{~cm} \text {, kemudian yang ditanyakan } \\
\text { luas daerah yang diarsir terus jawabannya adalah jika arsiran itu digabung maka } \\
\text { akan menghasilkan satu persegi kecil utuh .......MS1 } \\
\text { Berdasarkan langkah-langkah yang telah kamu susun, bisakah kamu } \\
\text { memperkirakan bagiamana hasil akhir yang akan kamu dapatkan? Misalnya } \\
\text { hasilnya nanti bilangan bulat, desimalkah? } \\
\text { Bisa, dalam bentuk angka. Hasil akhirnya nanti adalah bilangan bulat ........MS2 }\end{array}$ \\
\hline
\end{tabular}

Berdasarkan informasi pada Gambar 6 dan Tabel 14, subjek FA mampu menentukan langkah-langkah yang akan digunakan untuk mendapatkan solusi penyelesaian yaitu dengan cara menganalisis gambar yang terdapat pada soal dan memperoleh hasil analisis bahwa jika daerah yang diarsir itu dipindahkan dan digabungkan maka akan membentuk bangun persegi kecil (ditunjukkan oleh MS1). Hal tersebut sejalan dengan pendapat Fajriyah (2019) yang menyebutkan bahwa students with fast accurate cognitive style were able to master representation and devising strategies for solving problems dan juga sejalan dengan Rozencwajg (2005) yang menyatakan bahwa

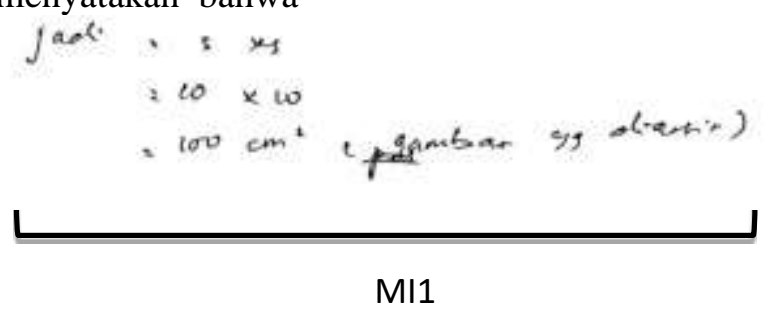

Gambar 7. Kutipan Jawaban Subjek FA pada Langkah Melaksanakan Rencana Penyelesaian fast accurate individuals, who are capable of implementing analytic. Selain itu, dia juga mampu memprediksi hasil dari langkahlangkah yang telah ditentukan sebelumnya dengan tepat (ditunjukkan dengan MS2). Dengan demikian, dapat dikatakan bahwa dia mampu melakukan strategi pada langkah membuat rencana penyelesaian.

Selanjutnya akan disajikan kutipan tes tertulis dan transkrip wawancara subjek FA mengenai kemampuan berpikir kritis pada langkah melaksanakan rencana penyelesaian. 
Tabel 15. Transkrip Wawancara Subjek FA pada Langkah Melaksanakan Rencana Penyelesaian

\begin{tabular}{|c|c|}
\hline $\begin{array}{c}\text { Kode } \\
\text { Wawancara }\end{array}$ & Transkrip Wawancara \\
\hline $\mathrm{QFA}_{14}$ & $\begin{array}{l}\text { Itu tadi kan cuma pikiranmu aja? Nah, pas kamu melakukan perhitungan apakah } \\
\text { tetap menggunakan langkah-langkah yang sudah kamu pikirkan sebelumnya atau } \\
\text { langkah-langkahnya ada yang kamu tambahi atau kurangi? }\end{array}$ \\
\hline $\mathrm{AFA}_{14}$ & $\begin{array}{l}\text { Tetep pakek cara yang pertama, tapi nanti kalau ada kesusahan bisa ganti rumus } \\
\text { atau tambah rumus. Waktu saya_mengerjakan kemarin tetap menggunakan } \\
\text { rencana awal, tidak ditambah ataupun dikurangi rencana awal saya ........MI1 }\end{array}$ \\
\hline $\mathrm{QFA}_{15}$ & Kesimpulan apa yang kamu dapatkan? \\
\hline $\mathrm{AFA}_{15}$ & Kesimpulannya, luas daerah yang diarsir adalah $100 \mathrm{~cm}^{2}$ \\
\hline $\mathrm{QFA}_{16}$ & $\begin{array}{l}\text { Apakah kamu yakin bahwa kesimpulanmu tadi sesuai dengan yang ditanyakan } \\
\text { pada soal? }\end{array}$ \\
\hline $\mathrm{AFA}_{16}$ & Yakin, karena memang saya mencari seperti yang disuruh dalam soal. \\
\hline
\end{tabular}

Berdasarkan informasi pada Gambar 7 dan Tabel 15, subjek FA mampu melaksanakan semua langkah-langkah yang telah direncanakan sebelumnya (ditunjukkan oleh MI1), sehingga dapat menarik kesimpulan yang tepat (ditunjukkan oleh MI2), namun tidak didukung dengan alasan yang masuk akal (ditunjukkan oleh $\mathrm{AFA}_{16}$ ). Hal tersebut berbeda dengan Fajriyah (2019) yang menyatakan bahwa students with fast accurate cognitive style were able to reasoning and argumentation were quite well mastered. Perbedaan tersebut dapat terjadi dikarenakan subjek bergaya kognitif fast accurate terlalu cepat dalam memberikan jawaban sehingga jawaban yang diberikan tidak dikoreksi terlebih dahulu sebelum diutarakan. Dengan demikian, dapat dikatakan bahwa dia tidak mampu melakukan inferensi pada langkah melaksanakan rencana penyelesaian.

Kemudian, berikut ini juga akan disajikan transkrip wawancara terhadap subjek FA mengenai kemampuan berpikir kritis pada langkah memeriksa kembali.

Tabel 16. Transkrip Wawancara Subjek FA pada Langkah Memeriksa Kembali

\begin{tabular}{c|l}
$\begin{array}{c}\text { Kode } \\
\text { Wawancara }\end{array}$ & \multicolumn{1}{c}{ Transkrip Wawancara } \\
\hline QFA $_{17}$ & $\begin{array}{l}\text { Kan kamu sudah mendapat jawabannya, apakah kamu memeriksa kembali } \\
\text { langkah-langkah mu dari awal sampai ahkir sampai didapatkan solusi } \\
\text { penyelesaian. } \\
\text { Tidak, karena saya sudah bingung jadi langsung saya kumpulkan. } \\
\text { Apakah kamu memikirkan cara lain yang dapat kamu gunakan selain langkah- } \\
\text { langkah yang telah kamu tulis ini untuk mendapatkan luas daerah yang diarsir ini? }\end{array}$ \\
QFA $_{18}$ & $\begin{array}{l}\text { Tidak, karena saya cuma dapat satu pandangan saja. } \\
\text { Kesimpulan apakah yang kamu peroleh setelah melakukan serangkaian proses } \\
\text { untuk mendapatkan solusi penyelesaian dari soal tersebut? }\end{array}$ \\
AFA $_{18}$ & $\begin{array}{l}\text { Bahwa persegi ABCD tersusun dari empat persegi kecil, dan persegi kecil itu } \\
\text { tersusun dari arsiran yang ditanyakan ........MI4 }\end{array}$ \\
\hline
\end{tabular}

Berdasarkan Tabel 16, subjek FA tidak memeriksa kembali semua langkah yang telah dilakukan (ditunjukkan oleh $\mathrm{AFA}_{17}$ ) dan tidak mampu menemukan cara lain yang dapat digunakan untuk mendapatkan solusi penyelesaian tersebut (ditunjukkan oleh $\mathrm{AFA}_{18}$ ), sehingga dapat dikatakan bahwa dia tidak mampu melakukan strategi pada langkah memeriksa kembali. Namun dia mampu membuat generalisasi (ditunjukkan oleh MI4), sehingga dapat dikatakan bahwa dia mampu melakukan inferensi pada langkah memeriksa kembali.
4. Kemampuan Berpikir Kritis Siswa SMP yang Bergaya Kognitif Slow Inaccurate dalam Memecahkan Masalah Matematika

Berikut ini akan disajikan transkrip wawancara terhadap subjek SI mengenai kemampuan berpikir kritis pada langkah memahami masalah. 
Tabel 17. Transkrip Wawancara Subjek SI pada Langkah Memahami Masalah

\begin{tabular}{|c|c|}
\hline $\begin{array}{c}\text { Kode } \\
\text { Wawancara }\end{array}$ & Transkrip Wawancara \\
\hline $\mathrm{QSI}_{1}$ & $\begin{array}{l}\text { Berapa kali kamu membaca soal yang terdapat pada tes pemecahan masalah } \\
\text { matematika? }\end{array}$ \\
\hline $\mathrm{ASI}_{1}$ & Tiga \\
\hline $\mathrm{QSI}_{2}$ & Coba kamu sebutkan apa saja yang diketahui dari soal? \\
\hline $\mathrm{ASI}_{2}$ & Panjang sisi persegi kecil $10 \mathrm{~cm}$........MK1 \\
\hline $\mathrm{QSI}_{3}$ & Berhubungan dengan materi apakah soal tersebut? \\
\hline $\mathrm{ASI}_{3}$ & Luas lingkaran dan luas segitiga \\
\hline $\mathrm{QSI}_{4}$ & $\begin{array}{l}\text { Coba kamu jelaskan kembali soal yang ada pada tes pemecahan masalah } \\
\text { matematika tersebut dengan menggunakan bahasamu sendiri! }\end{array}$ \\
\hline $\mathrm{ASI}_{4}$ & Menentukan luas daerah yang diarsir berdasarkan gambar \\
\hline $\mathrm{QSI}_{5}$ & Coba kamu jelaskan apa yang ditanyakan dari soal? \\
\hline $\mathrm{ASI}_{5}$ & Menentukan luas daerah yang diarsir .......MK2 \\
\hline $\mathrm{QSI}_{6}$ & Apakah terdapat hubungan antara yang diketahui dan yang ditanyakan? \\
\hline $\mathrm{ASI}_{6}$ & Ada, kita dapat menentukan luas daerah yang diarsir dari yang diketahui. \\
\hline $\mathrm{QSI}_{7}$ & $\begin{array}{l}\text { Menurut pendapat kamu apakah soal ini berhubungan dengan materi lain pada } \\
\text { matematika? }\end{array}$ \\
\hline $\mathrm{ASI}_{7}$ & Tidak \\
\hline $\mathrm{QSI}_{8}$ & Apa saja kata kunci yang terdapat dalam soal tersebut? \\
\hline $\mathrm{ASI}_{8}$ & Panjang sisi persegi kecil $10 \mathrm{~cm}$.......MK4 \\
\hline $\mathrm{QSI}_{9}$ & Coba kamu sebutkan informasi-informasi yang saling berhubungan pada soal! \\
\hline $\mathrm{ASI}_{9}$ & $\begin{array}{l}\text { Luas persegi dikurangi luas seperempat lingkaran, luas seperempat lingkaran } \\
\text { dikurangi luas segitiga ........MA1 }\end{array}$ \\
\hline $\mathrm{QSI}_{10}$ & Mengapa informasi-informasi yang kamu sebutkan tadi saling berhubungan? \\
\hline $\mathrm{ASI}_{10}$ & Karena bisa menemukan luas daerah yang diarsir .......MA2 \\
\hline $\mathrm{QSI}_{11}$ & $\begin{array}{l}\text { Dari informasi-informasi yang telah kamu sebutkan tadi, informasi manakah yang } \\
\text { akan kamu gunakan untuk mendapatkan solusi penyelesaian? }\end{array}$ \\
\hline $\mathrm{ASI}_{11}$ & Yang ini (digunakan semuanya) ........MA3 \\
\hline
\end{tabular}

Berdasarkan informasi pada Tabel 17, subjek SI membaca soal sebanyak 3 kali (ditunjukkan oleh $\mathrm{ASI}_{1}$ ). Dia mampu menyebutkan informasi yang diketahui (ditunjukkan oleh MK1), informasi yang ditanyakan (ditunjukkan oleh MK2), namun tidak mampu menyebutkan hubungan antara yang diketahui dan ditanya serta materi matematika yang terkait dengan soal tersebut (ditunjukkan oleh $\mathrm{ASI}_{6}$ dan $\mathrm{ASI}_{7}$ ), dan juga mampu menyebutkan kata kunci yang terdapat pada soal (ditunjukkan oleh MK4). Dengan demikian, dapat dikatakan bahwa dia tidak mampu melakukan klarifikasi pada langkah memahami masalah. Selain itu dia juga mampu menyebutkan informasi-informasi yang saling berhubungan pada soal (ditunjukkan oleh MA1) disertai dengan alasan yang mendukung (ditunjukkan oleh MA2) sehingga mampu memutuskan informasi mana yang akan digunakan untuk mendapatkan solusi penyelesaian (ditunjukkan oleh MA3). Hal tersebut sesuai dengan Fajriyah (2019) yang menyebutkan bahwa students with slow inaccurate cognitive style were quite well to master reasoning and argumentation. Dengan demikian, dapat dikatakan bahwa dia mampu melakukan asesmen pada langkah memahami masalah.

Berikutnya akan disajikan transkrip wawancara terhadap subjek SI mengenai kemampuan berpikir kritis pada langkah membuat rencana penyelesaian.

Tabel 18. Transkrip Wawancara Subjek SI pada Langkah Membuat Rencana Penyelesaian

\begin{tabular}{c|l}
\hline $\begin{array}{c}\text { Kode } \\
\text { Wawancara }\end{array}$ & \multicolumn{1}{c}{ Transkrip Wawancara } \\
\hline QSI $_{12}$ & $\begin{array}{l}\text { Langkah-langkah apa yang lakukan untuk mendapatkan solusi penyelesaian dari } \\
\text { soal tersebut? } \\
\text { Luas persegi dikurangi luas seperempat lingkaran sehingga akan didapatkan } \\
\text { sebagian dari luas daerah yang diarsir, kemudian luas seperempat lingkaran } \\
\text { dikurangi luas segitiga juga akan didapatkan sebagian dari luas daerah yang } \\
\text { diarsir, setelah itu kedua luas daerah yang diarsir tersebut ditambahkan dengan } \\
\text { luas segitiga, dengan demikian akan didapatkan luas daerah yang diarsir secara } \\
\text { keseluruhan ........MS1 }\end{array}$ \\
\hline
\end{tabular}




\begin{tabular}{c|l}
\hline $\begin{array}{c}\text { Kode } \\
\text { Wawancara }\end{array}$ & \multicolumn{1}{c}{ Transkrip Wawancara } \\
\hline QSI $_{13}$ & $\begin{array}{l}\text { Berdasarkan langkah-langkah yang telah kamu susun, bisakah kamu } \\
\text { memperkirakan bagiamana hasil akhir yang kamu dapatkan? Misalnya hasilnya } \\
\text { nanti bilangan bulat, desimalkah? }\end{array}$ \\
$\mathrm{ASI}_{13}$ & \begin{tabular}{l} 
Enggak memikirkan hasil akhirnya seperti apa \\
\hline
\end{tabular}
\end{tabular}

Berdasarkan infromasi pada Tabel 18, subjek SI mampu menentukan langkah-langkah yang akan digunakan untuk mendapatkan solusi penyelesaian yaitu dengan membagi gambar menjadi beberapa bagian untuk mencari luas daerah yang diarsir secara satu persatu (ditunjukkan oleh MS1). Hal tersebut sejalan dengan Fajriyah (2019) yang menyatakan bahwa students with slow inaccurate cognitive style were quite well to master devising strategies for solving problems. Namun tidak mampu memprediksi hasil dari langkahlangkah yang telah disusun sebelumnya dengan tepat, sehingga dia tidak memikirkan hasil akhirnya seperti apa (ditunjukkan oleh $\mathrm{ASI}_{13}$ ). Dengan demikian, dapat dikatakan bahwa dia tidak mampu melakukan strategi pada langkah membuat rencana penyelesaian.

Selanjutnya akan disajikan kutipan tes tertulis dan transkrip wawancara subjek SI mengenai kemampuan berpikir kritis pada langkah melaksanakan rencana penyelesaian.

MI1

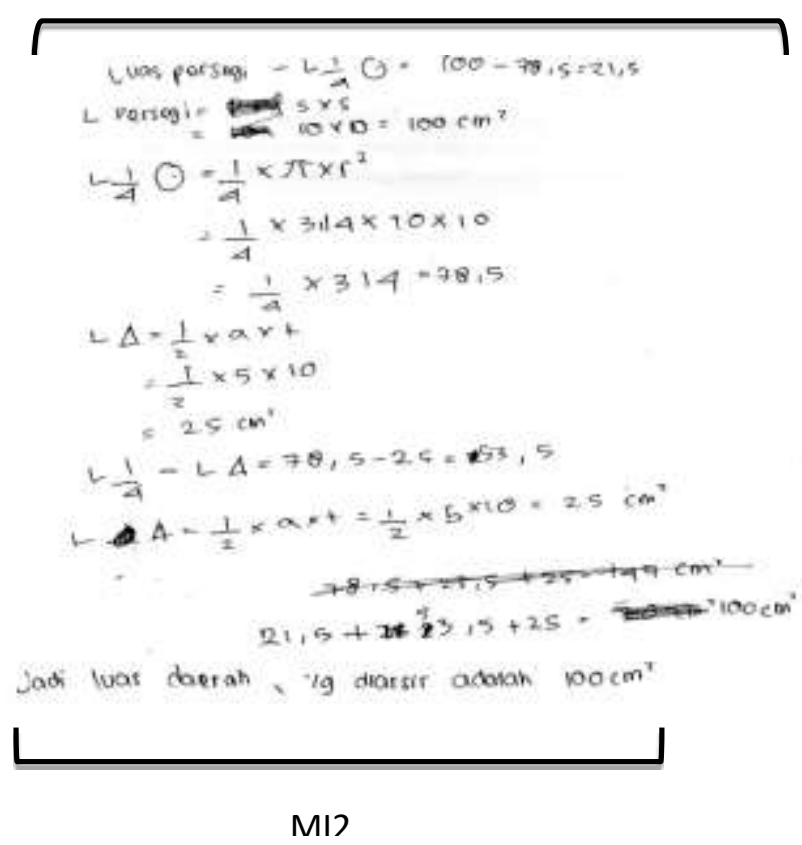

Gambar 8. Kutipan Jawaban Subjek SI pada Langkah Melaksanakan Rencana Penyelesaian

Tabel 19. Transkrip Wawancara Subjek SI pada Langkah Melaksanakan Rencana Penyelesaian

\begin{tabular}{c|l}
\hline $\begin{array}{c}\text { Kode } \\
\text { Wawancara }\end{array}$ & \multicolumn{1}{c}{ Transkrip Wawancara } \\
\hline QSI $_{14}$ & $\begin{array}{l}\text { Kan habis memikirkan langkah-langkahnya kan kamu melakukan perhitungan. } \\
\text { Nah, pas kamu melakukan perhitungan apakah tetap melaksanakan langkah- } \\
\text { langkah awal mu tadi atau enggak? }\end{array}$ \\
ASI $_{14}$ & $\begin{array}{l}\text { Enggak, langkah-langkahnya sama persis seperti rencana awal .......MI1 } \\
\text { QSI }_{15}\end{array}$ \\
ASI I $_{15}$ & $\begin{array}{l}\text { Kita dapat menemukan luas daerah yang diarsir yaitu 100 cm ........MI2 } \\
\text { Apakah kamu yakin bahwa kesimpulanmu yang kamu dapatkan sudah sesuai } \\
\mathrm{QSI}_{16}\end{array}$ \\
$\mathrm{ASI}_{16}$ & $\begin{array}{l}\text { dengan yang ditanyakan pada soal? } \\
\text { Sudah yakin, karena saya sudah menemukan jawabannya }\end{array}$ \\
\hline
\end{tabular}

Berdasarkan informasi pada Gambar 8 dan Tabel 19, subjek SI mampu melaksanakan semua langkah-langkah yang telah direncanakan sebelumnya (ditunjukkan oleh
MI1), sehingga dapat menarik kesimpulan yang tepat (ditunjukkan oleh MI2), namun tidak mampu memberikan alasan yang masuk akal (ditunjukkan oleh $\mathrm{ASI}_{16}$ ). Dengan demikian, 
dapat dikatakan bahwa dia tidak mampu melakukan inferensi pada langkah melaksanakan rencana penyelesaian.
Kemudian, berikut ini juga akan disajikan transkrip wawancara terhadap subjek SI mengenai kemampuan berpikir kritis pada langkah memeriksa kembali.

Tabel 20. Transkrip Wawancara Subjek SI pada Langkah Memeriksa Kembali

\begin{tabular}{c|l}
$\begin{array}{c}\text { Kode } \\
\text { Wawancara }\end{array}$ & \multicolumn{1}{c}{ Transkrip Wawancara } \\
\hline QSI $_{17}$ & $\begin{array}{l}\text { Apakah kamu memeriksa kembali langkah-langkah mu dari awal sampai ahkir } \\
\text { sampai didapatkan solusi penyelesaian. }\end{array}$ \\
ASI $_{17}$ & $\begin{array}{l}\text { Iya .......MS3 } \\
\text { Apakah ada cara lain yang dapat kamu gunakan untuk menemukan solusi } \\
\text { penyelesaian dari soal tersebut? }\end{array}$ \\
ASI $_{18}$ & $\begin{array}{l}\text { Tidak } \\
\text { Kesimpulan apakah yang kamu peroleh setelah melakukan serangkaian proses } \\
\text { untuk mendapatkan solusi penyelesaian dari soal tersebut? }\end{array}$ \\
ASI $_{19}$ & $\begin{array}{l}\text { Setiap daerah yang diarsir memiliki cara tersendiri untuk mendapatkan berapa } \\
\text { luasannya ........MI4 }\end{array}$ \\
\hline
\end{tabular}

Berdasarkan infromasi pada Tabel 20, subjek SI mampu memeriksa kembali semua langkah yang telah dilakukan dari awal sampai akhir (ditunjukkan oleh MS3), namun tidak mampu menemukan cara lain yang dapat digunakan untuk mendapatkan solusi penyelesaian tersebut (ditunjukkan oleh $\mathrm{ASI}_{18}$ ). Dengan demikian, dapat dikatakan bahwa dia tidak mampu melakukan strategi pada langkah memeriksa kembali. Selain itu, dia mampu membuat generalisasi (ditunjukkan oleh MI4), sehingga dapat dikatakan bahwa dia mampu melakukan inferensi pada langkah memeriksa kembali.

\section{Simpulan}

Berdasarkan hasil analisis data dan pembahasan, maka dapat ditarik simpulan sebagai berikut.

1. Siswa SMP yang bergaya kognitif reflektif dalam memecahkan masalah matematika pada langkah memahami masalah, mampu menyebutkan informasi-informasi yang terdapat pada soal, menentukan pokok permasalahan secara tepat, mengaitkan informasi-informasi yang saling berhubungan dan mengaitkan permasalahan dengan materi lain yang akan digunakan dalam penyelesaian, serta mendefinisikan istilah-istilah yang relevan dari permasalahan yang diberikan, yang berarti dia telah mampu melakukan klarifikasi. Dia juga mampu menyebutkan informasi-informasi relevan yang terdapat pada soal, mendeskripsikan alasan terhadap informasiinformasi relevan yang telah ditemukan, dan menentukan informasi relevan yang tepat yang akan digunakan untuk mendapatkan solusi penyelesaian, yang berarti dia juga telah mampu melakukan asesmen. Pada langkah membuat rencana penyelesaian, dia mampu menentukan langkah-langkah yang akan digunakan untuk mendapatkan solusi penyelesaian dan memprediksi hasil akhir dari langkah-langkah yang telah ditentukan sebelumnya dengan tepat beserta alasan yang masuk akal, yang berarti dia telah mampu melakukan strategi. Pada langkah melaksanakan rencana penyelesaian, dia mampu melaksanakan pemecahan masalah menggunakan langkah-langkah yang telah direncanakan sebelumnya, menyimpulkan secara tepat sesuai dengan solusi yang didapatkan dari langkah-langkah pemecahan masalah yang telah dilakukan, dan mendeskripsikan alasan yang tepat mengenai kesimpulan yang didapatkan, yang berarti dia telah mampu melakukan inferensi. Pada langkah memeriksa kembali, dia mampu memeriksa kembali langkah-langkah yang telah dilakukan, namun tidak mampu menentukan langkah lain yang sesuai sehingga dapat digunakan untuk mendapatkan solusi penyelesaian, yang berarti dia tidak mampu melakukan strategi. Tetapi dia mampu membuat generalisasi sesuai dengan hasil yang diperoleh dengan tepat, yang berarti dia telah mampu melakukan inferensi.

2. Siswa SMP yang bergaya kognitif impulsif dalam memecahkan masalah matematika pada langkah memahami masalah, mampu menyebutkan informasi-informasi yang terdapat pada soal, menentukan pokok permasalahan secara tepat, mendefinisikan istilah-istilah yang relevan dari permasalahan yang diberikan, mengaitkan permasalahan dengan materi lain yang akan digunakan dalam penyelesaian, namun dia tidak mampu mengaitkan informasi-informasi yang saling berhubungan, yang berarti dia tidak mampu melakukan klarifikasi. Dia juga mampu menentukan informasi relevan yang tepat yang 
akan digunakan untuk mendapatkan solusi penyelesaian, namun tidak mampu menyebutkan informasi-informasi relevan yang terdapat pada soal dan juga tidak mampu mendeskripsikan alasan terhadap informasiinformasi relevan yang telah ditemukan, yang berarti dia juga tidak mampu melakukan asesmen. Pada langkah membuat rencana penyelesaian, dia mampu menentukan langkahlangkah yang akan digunakan untuk mendapatkan solusi penyelesaian dan memprediksi hasil akhir dari langkah-langkah yang telah ditentukan sebelumnya dengan tepat beserta alasan yang masuk akal, yang berarti dia mampu melakukan strategi. Pada langkah melaksanakan rencana penyelesaian, dia mampu melaksanakan pemecahan masalah menggunakan langkah-langkah yang telah direncanakan sebelumnya, menyimpulkan secara tepat sesuai dengan solusi yang didapatkan dari langkah-langkah pemecahan masalah yang telah dilakukan, namun dia tidak mampu mendeskripsikan alasan yang tepat mengenai kesimpulan yang didapatkan, yang berarti dia tidak mampu melakukan inferensi. Pada langkah memeriksa kembali, dia mampu memeriksa kembali langkah-langkah yang telah dilakukan dan menentukan langkah lain yang sesuai sehingga dapat digunakan untuk mendapatkan solusi penyelesaian, yang berarti dia telah mampu melakukan strategi. Dia juga mampu membuat generalisasi sesuai dengan hasil yang diperoleh dengan tepat, yang berarti dia mampu melakukan inferensi.

3. Siswa SMP yang bergaya kognitif fast accurate dalam memecahkan masalah matematika pada langkah memahami masalah, mampu menyebutkan informasi-informasi yang terdapat pada soal, menentukan pokok permasalahan secara tepat, mendefinisikan istilah-istilah yang relevan dari permasalahan yang diberikan, mengaitkan permasalahan dengan materi lain yang akan digunakan dalam penyelesaian, namun dia tidak mampu mengaitkan informasi-informasi yang saling berhubungan, yang berarti dia tidak mampu melakukan klarifikasi. Dia mampu menentukan informasi relevan yang tepat yang akan digunakan untuk mendapatkan solusi penyelesaian, namun dia tidak mampu menyebutkan informasi-informasi relevan yang terdapat pada soal dan juga tidak mampu mendeskripsikan alasan terhadap informasiinformasi relevan yang telah ditemukan, yang berarti dia juga tidak mampu melakukan asesmen. Pada langkah membuat rencana penyelesaian, dia mampu menentukan langkah- langkah yang akan digunakan untuk mendapatkan solusi penyelesaian dan memprediksi hasil akhir dari langkah-langkah yang telah ditentukan sebelumnya dengan tepat beserta alasan yang masuk akal, yang berarti dia mampu melakukan strategi. Pada langkah melaksanakan rencana penyelesaian, dia mampu melaksanakan pemecahan masalah menggunakan langkah-langkah yang telah direncanakan sebelumnya, menyimpulkan secara tepat sesuai dengan solusi yang didapatkan dari langkah-langkah pemecahan masalah yang telah dilakukan, namun tidak mampu mendeskripsikan alasan yang tepat mengenai kesimpulan yang didapatkan, yang berarti dia tidak mampu melakukan inferensi. Pada langkah memeriksa kembali, dia tidak mampu memeriksa kembali langkah-langkah yang telah dilakukan dan juga tidak mampu menentukan langkah lain yang sesuai sehingga dapat digunakan untuk mendapatkan solusi penyelesaian, yang berarti dia tidak mampu melakukan strategi. Namun dia mampu membuat generalisasi sesuai dengan hasil yang diperoleh dengan tepat, yang berarti dia mampu melakukan inferensi.

4. Siswa SMP yang bergaya kognitif slow inaccurate dalam memecahkan masalah matematika pada langkah memahami masalah, mampu menyebutkan informasi-informasi yang terdapat pada soal, menentukan pokok permasalahan secara tepat, mendefinisikan istilah-istilah yang relevan dari permasalahan yang diberikan, namun dia tidak mampu mengaitkan informasi-informasi yang saling berhubungan dan tidak mampu mengaitkan permasalahan dengan materi lain yang akan digunakan dalam penyelesaian, yang berarti dia tidak mampu melakukan klarifikasi. Dia mampu menyebutkan informasi-informasi relevan yang terdapat pada soal, mendeskripsikan alasan terhadap informasiinformasi relevan yang telah ditemukan, dan menentukan informasi relevan yang tepat yang akan digunakan untuk mendapatkan solusi penyelesaian, yang berarti dia telah mampu melakukan asesmen. Pada langkah membuat rencana penyelesaian, dia mampu menentukan langkah-langkah yang akan digunakan untuk mendapatkan solusi penyelesaian, namun dia tidak mampu memprediksi hasil akhir dari langkah-langkah yang telah ditentukan sebelumnya dengan tepat beserta alasan yang masuk akal, yang berarti dia tidak mampu melakukan strategi. Pada langkah melaksanakan rencana penyelesaian, dia mampu melaksanakan pemecahan masalah 
menggunakan langkah-langkah yang telah direncanakan sebelumnya dan menyimpulkan secara tepat sesuai dengan solusi yang didapatkan dari langkah-langkah pemecahan masalah yang telah dilakukan, namun dia tidak mampu mendeskripsikan alasan yang tepat mengenai kesimpulan yang didapatkan, yang berarti dia tidak mampu melakukan inferensi. Pada langkah memeriksa kembali, dia mampu memeriksa kembali langkah-langkah yang telah dilakukan, namun dia tidak mampu menentukan langkah lain yang sesuai sehingga dapat digunakan untuk mendapatkan solusi penyelesaian, yang berarti dia tidak mampu melakukan strategi. Namun dia mampu membuat generalisasi sesuai dengan hasil yang diperoleh dengan tepat, yang berarti dia telah mampu melakukan inferensi.

\section{Daftar Pustaka}

Appulembang, Oce Datu. 2017. "Profil Pemecahan Masalah Aljabar Berpandu pada Taksonomi Solo Ditinjau dari Gaya Kognitif Konseptual Tempo Siswa SMA Negeri 1 Makale Tana Toraja". Journal of Language, Literature, Culture, and Education.Vol. 13 (2): 133-149.

Ardani, Shinta Hapsari dan Ismail. 2017. "Profil Berpikir Kritis Siswa SMP dalam Memecahkan Masalah Matematika Ditinjau dari Gaya Kognitif dan Jenis Kelamin". Jurnal Ilmiah Pendidikan Matematika MATHEdunesa. Vol. 6 (2): hal. 184-192.

Departemen Pendidikan Nasional. 2007. Modelmodel Pembelajaran Matematika dan Ilmu Pengetahaun Alam. Jakarta: Direktorat PSLB.

Desmita. 2009. Psikologi Perkembangan Peserta Didik. Bandung: PT Remaja Rosdakarya.

Dyah, Nindya Waspaning dan Rini Setianingsih. 2019. "Critical Thinking Processes Of Junior High Scholl in Solving Contextual Problems of Direct and Inverse Proportions Based on Reflective-Impusive Style". Jurnal Ilmiah Pendidikan Matematika MATHEdunesa. Vol. 8 (2): hal. 311-317.

Fajriyah, Euis. 2019, dkk. 2019. "Mathematical Literacy Ability Reviewed from Cognitive Style of Students on Double Loop Problem Solving Model with RME Approach". Unnes Journal of Mathematics Education Research. Vol. 8 (1): hal. 57-64.

Mbagho, Hilaria Melania. 2015. Profil Berpikir Kritis Siswa SMP dalam Memecahkan Masalah Geometri Kontekstual Ditinjau dari Perbedaan Kemampuan Matematika. Tesis tidak diterbitkan. Surabaya: PPs Universitas Negeri Surabaya.

Musfiqon, M dan Nurdyansyah. 2015. Pendekatan Pembelajaran Saintifik. Sidoarjo: Nizamia Learning Center.

Ningsih, Puji Rahayu. 2012. Profil Berpikir Kritis Siswa SMP dalam Menyelesaikan Masalah Matematika Berdasarkan Gaya Kognitif. Tesis tidak diterbitkan. Surabaya: PPs Universitas Negeri Surabaya.

Nisa', Roisatun. 2015. Profil Berpikir Kritis Siswa SMP dalam Menyelesaikan Soal Cerita Ditinjau dari Gaya Kognitif dan Kemampuan Matematika. Tesis tidak diterbitkan. Surabaya: PPs Universitas Negeri Surabaya.

Polya, G. 1973. How To Solve It Second Edition. Princeton, New Jersey: Princeton University Press.

Pusat Penelitian Pendidikan Kementerian Pendidikan dan Kebudayaan (Puspendik Kemendikbud). 2019. Laporan Hasil Ujian Nasional: Capaian Nasional, (online) https://pusmenjar.kemendikbud.go.id/hasilun I

Rofi'ah, Khofidhotur dan Masriyah. 2018. "Identifikasi Kemampuan Berpikir Kritis Siswa dalam Pemecahan Masalah Matematika Ditinjau dari Gaya Kognitif Reflektif dan Impulsif". Jurnal Ilmiah Pendidikan Matematika MATHEdunesa. Vol. 7 (3): hal. 550-556.

Rozencwajg, Paulette dan Denis Corroyer. 2005. "Cognitive Processes in the ReflectiveImpulsive Cognitive Style". The Journal of Genetic Psychology. Vol. 166 (4): hal. 451463.

Santrock, John W. 2009. Psikologi Pendidikan Edisi 3 Buku 2. Jakarta: Salemba Humanika.

Santrock, John W. 2009. Psikologi Pendidikan Edisi 5 Buku 1. Jakarta: Salemba Humanika.

Siswono, Tatag.Y. E. 2008. Model Pembelajaran Matematika Berbasis Pengajuan dan Pemecahan Masalah untuk Meningkatkan Kemampuan Berpikir Kreatif. Surabaya: UNESA University Press.

Slavin, Robert E. 2011. Psikologi Pendidikan Teori dan Praktik edisi kesembilan jilid 2. Jakarta: PT Indeks.

Sumiati, Ai dan Yenni Agustini. 2020. "Analisis Kesulitan Menyelesaikan Soal Segiempat dan Segitiga Siswa SMP Kelas VIII di Cianjur". Jurnal Cendekia Jurnal Pendidikan Matematika. Vol. 4 (01): hal. 321-330. 